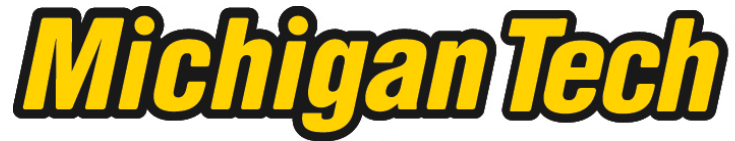 \\ Michigan Technological University Create the Future Digital Commons @ Michigan Tech
}

Dissertations, Master's Theses and Master's Reports - Open

Dissertations, Master's Theses and Master's

Reports

2011

Retrofitting boreholes contaminated with iron in rural Uganda

Caleb T. Fader

Michigan Technological University

Follow this and additional works at: https://digitalcommons.mtu.edu/etds

Part of the Civil and Environmental Engineering Commons

Copyright 2011 Caleb T. Fader

\section{Recommended Citation}

Fader, Caleb T., "Retrofitting boreholes contaminated with iron in rural Uganda ", Master's report, Michigan Technological University, 2011.

https://doi.org/10.37099/mtu.dc.etds/516

Follow this and additional works at: https://digitalcommons.mtu.edu/etds

3 Part of the Civil and Environmental Engineering Commons 


\title{
RETROFIT'TING BOREHOLES CONTAMINATED WITH IRON IN RURAL UGANDA
}

By

Caleb T. Fader

\author{
A REPORT \\ Submitted in partial fulfillment of the requirements for the degree of \\ MASTER OF SCIENCE \\ Civil Engineering
}

MICHIGAN TECHNOLOGICAL UNIVERSITY 2011

(C) 2011 Caleb T. Fader 
This report, "Retrofitting Boreholes Contaminated with Iron in Rural Uganda," is hereby approved in partial fulfillment of the requirements for the degree of Master of Science in Civil Engineering.

DEPARTMENT:

Civil and Environmental Engineering

Signatures:

Report Advisor:

Dr. John Gierke

Department Chair:

Dr. William Bulleit

Date: 


\section{TABLE OF CONTENTS}

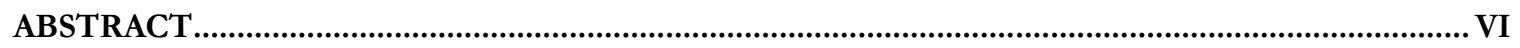

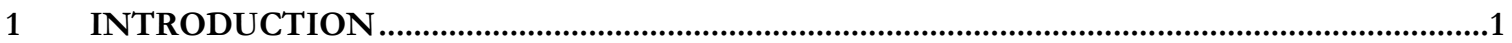

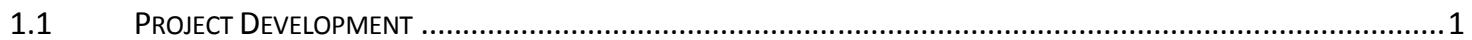

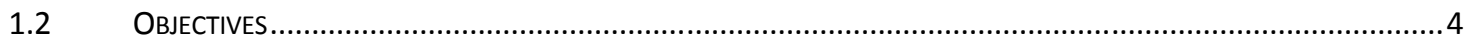

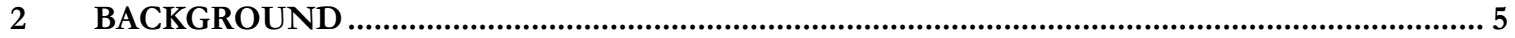

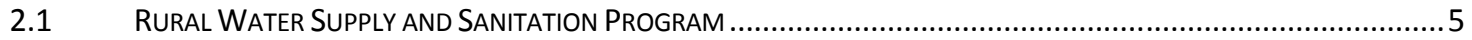

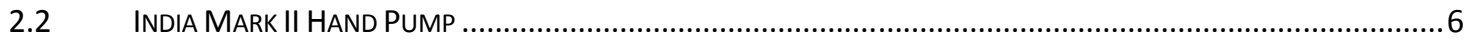

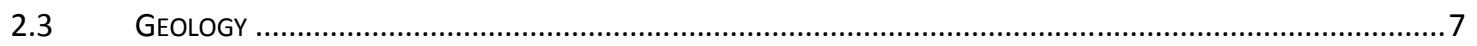

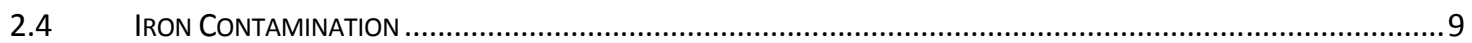

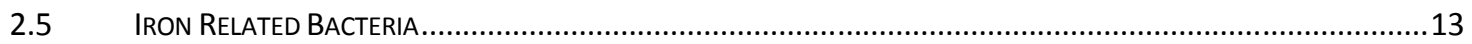

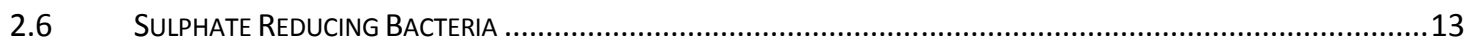

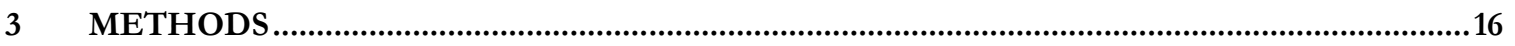

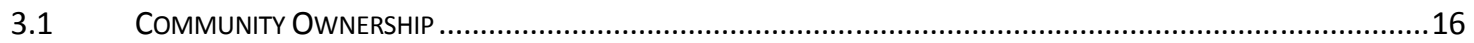

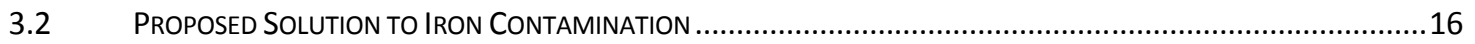

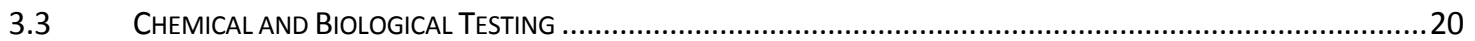

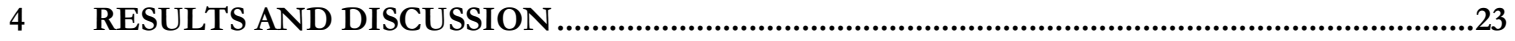

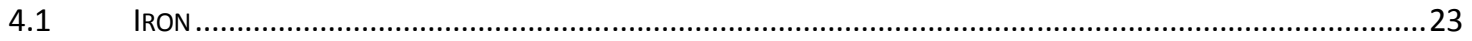

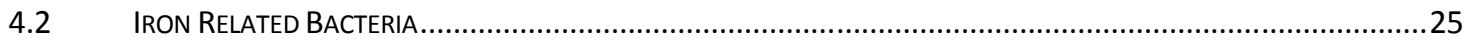

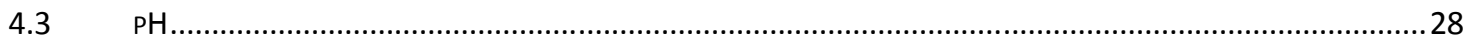

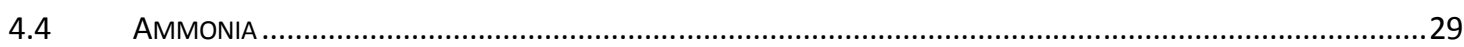

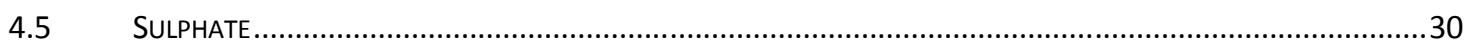

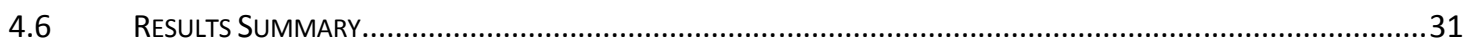

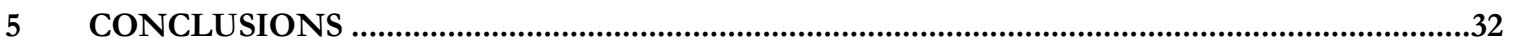

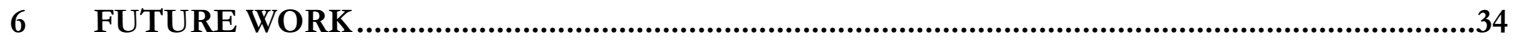

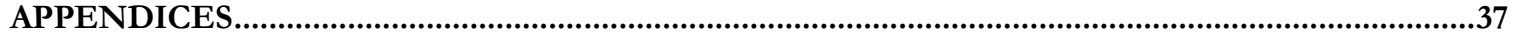

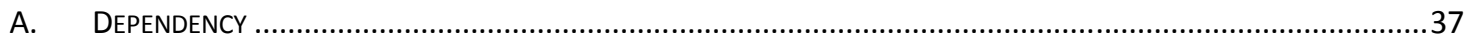

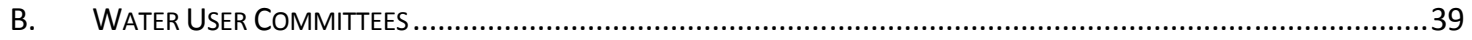

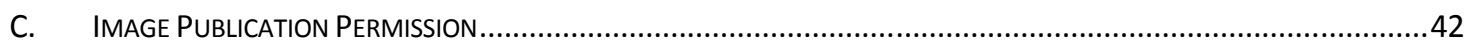

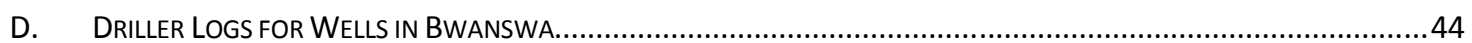

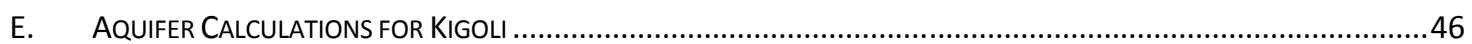




\section{LIST OF FIGURES}

FIGURE 1.1 LOCATION OF BWANSWA SUB-COUNTY WITHIN THE COUNTRY OF UGANDA (ADAPTED FROM

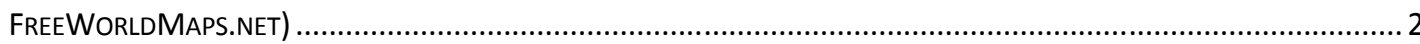

FIGURE 1.2 ORANGE SLIME FOUND ON GALVANIZED IRON RISER PIPES EXTRACTED FROM THE WELL IN BULEGETE

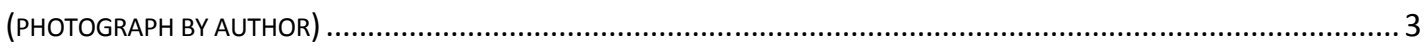

FIGURE 2.1 DIAGRAM OF THE INDIA MARK II HAND-PUMP (SKIPUMPS.COM) ........................................................... 7

FIGURE 2.2 BASIC GEOLOGY OF UGANDA (AdAPTED FROM THE GOVERNMENT OF UGANDA 2006) .................................. 8

FigURE 2.3 BUJUNE ALOYSIUS REFLECTS ON THE IRON-RICH WATER HE JUST DREW FROM THE KIGOLI BOREHOLE

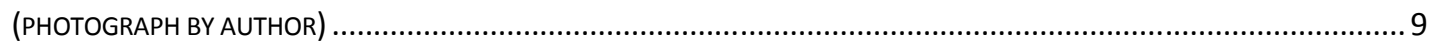

FigURE 2.4 CHILDREN FETCHING WATER FROM A TRADITIONAL UNPROTECTED SPRING (PHOTOGRAPH BY AUTHOR)...................10

FIGURE 2.5 SCHEMATIC PROFILE OF IRON REMOVAL PLANTS BEING RETROFITTED ONTO INDIA MARK II HAND PUMPS IN

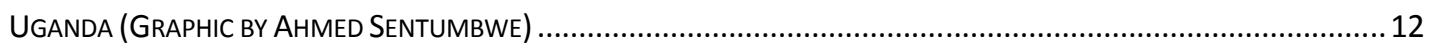

FigURE 2.6 A HOLE EATEN INTO AN IRON RISER PIPE FROM THE KYABASAIJA WELL (PHOTOGRAPH BY AUTHOR) ........................14

FIGURE 3.1 TAKING A BOILED CORN BREAK DURING THE BOREHOLE CONVERSION AT KIHURUMBA (PHOTOGRAPH BY AUTHOR)

FIGURE 3.2 FIRST DAY OF TESTING FOR IRB USING IRB-BART ${ }^{\text {TM }}$ TEST KITS (PHOTOGRAPH BY AUTHOR).

FIGURE 4.1 MEMBERS OF THE BULEGETE COMMUNITY ENJOYING THEIR RESTORED WATER SOURCE (PHOTOGRAPH BY AUTHOR)

FIGURE 4.2 FROM LEFT TO RIGHT: BUBBLES APPEARING IN IRB-BART ${ }^{T M}$ SAMPLES TAKEN FROM BUKUMI, KIGOLI, AND BulEgete. No Bubbles IN KANYAWAWA'S SAMPLE. (PHOTOGRAPH BY AUTHOR).

FigURE 4.3 FROM LEFT TO RIGHT: BLACK REACTION FROM KASOJO, SCARLET SAMPLES FROM KIHURUMBA AND BUKUMI, AND CLEAR GREEN REACTION FROM KIGOLI AND BULEGETE. (PHOTOGRAPH BY AUTHOR).....

Figure 6.1 Desitayo, Bulemu, and CAleb Fader (PHOtograph by Author) 


\section{LIST OF TABLES}

TABLE 2.1 TOTAL IRON LEVELS AT THE TIME OF WELL CONSTRUCTION

TABLE 3.1 ITEMIZED LIST OF PARTS NEEDED FOR A U2 TO U3M CONVERSION. PRICES GIVEN BY MULTIPLE INDUSTRIES LIMITED, KAMPALA, UGANDA IN 2010.

TABLE 3.2 SUMMARY OF WELLS CONVERTED AND THEIR CHARACTERISTICS

TABLE 3.3 APPROXIMATE BACTERIAL POPULATION IN CFU/ML AS A FUNCTION OF DAYS TO REACTION AS INDICATED BY IRB-BART ${ }^{\mathrm{TM}}$ KITS

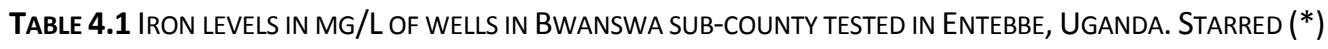
COLUMN TESTED IN HOUGHTON, MI.

TABLE 4.2 APPROXIMATE BACTERIAL POPULATIONS IN CFU/ML AS INDICATED BY IRB-BART ${ }^{T M}$ KITS. (P) INDICATES PLASTIC RISER PIPES AND (I) INDICATES GALVANIZED IRON RISER PIPES.

TABle 4.3 PH VALUeS OVER TIME. StARRED $\left({ }^{*}\right)$ VALUES WERE MEASURED AFTER PIPE CONVERSION AND DISINFECTION (EXCEPT NO DISINFECTION AT BULEGETE)

TABLE 4.4 SULPHATE VALUES OF WELLS WITH IRON COMPONENTS 30

TABLE 4.5 SulPhate VALUES IN MG/L OF WELls ChANGED to PLASTIC 30

TABLE 4.6 SUMMARY OF THE MOST RECENT CHARACTERISTICS OF THE FIVE CONVERTED WELLS 


\begin{abstract}
During my Peace Corps service as a community health liaison in rural Uganda I noticed that many improved water wells in our area had been abandoned. The communities described the water in these wells as being reddish in color, having a foul taste and odor, discoloring clothes and food, and not able to produce lather for washing.

Personal investigations and an initial literature search suggested that the primary contaminant was iron. The water in these wells had a low $\mathrm{pH}$ and a rusty metallic smell. The water produced early in the morning appeared very red but the water became more transparent as pumping continued. The iron components of many of these wells experienced accelerated corrosion resulting in frequent pump failure. This rapid corrosion coupled with the timing of the onset of iron contamination (months to years after these wells were completed) suggests that the most likely cause of the poor quality water was iron related bacteria and/or sulphate reducing bacteria.

This report describes a remedy for iron contamination employed at 5 wells. The remedy involved disinfecting the wells with chlorine and replacing iron pump components with plastic and stainless steel. Iron concentrations in the wells were less than $1 \mathrm{mg} / \mathrm{L}$ when the wells were drilled but ranged from 2.5 to $40 \mathrm{mg} / \mathrm{L}$ prior to the remedy. After the remedy was applied, the total iron concentrations returned to levels below $1 \mathrm{mg} / \mathrm{L}$. The presence of iron related bacteria was measured in all of these wells using Biological Activity Reaction Tests. Although IRB are still present in all the wells, the dissolved iron concentrations remain less than $1 \mathrm{mg} / \mathrm{L}$. This remedy is practical for rural areas because the work can be performed with only hand tools and costs less than US $\$ 850$. Because the source of iron contamination is removed in this approach, substantial follow-up maintenance is not necessary.
\end{abstract}




\section{INTRODUCTION}

The World Health Organization estimates that only $61 \%$ of people living on the African continent have access to an improved water source ${ }^{1}$ (WHO 2010). This figure is increasing with the recent global push to meet the Millennium Development Goals, but it remains a dismal percentage in comparison to the developed world. Additionally, many regions of Africa lack institutional structures to keep the improved water sources functioning properly. These two issues combine to threaten the health of a large percentage of African people.

\subsection{Project Development}

My Peace Corps service brought me to Bwanswa sub-county in Western Uganda (Figure 1.1). I was assigned to work with the Kyabasaija Village Development Program (KVDP) as a community heath liaison in early 2009. This relatively young and motivated community-based organization proved to be an essential component in developing a working relationship with the surrounding communities.

They had begun their work by carrying out a baseline survey of the main health concerns in the surrounding communities. A majority of the communities responded by saying that clean water was a significant problem, in addition to widespread poverty and malaria. Further investigation revealed that although the area had some improved water sources, the majority of them had been abandoned because of poor water quality or because the pump was broken.

The local government of Bwanswa estimates that in its roughly 100 square kilometer area there are 218 water access points. Of these, 86 are improved: 33 protected springs, 23 shallow wells, and 30 boreholes. Upon my arrival, only 11 of the boreholes were functioning; the remaining 19 were not in use due to poor water quality (12) and pump hardware malfunction (7).

\footnotetext{
${ }^{1}$ Improved drinking water sources are defined by the WHO in terms of the types of technology and levels of services that are more likely to provide safe water than unimproved technologies. Examples of improved water sources are as follows: household connections, public standpipes, boreholes, protected dug wells, protected springs, and rainwater collections (WHO 2010).
} 


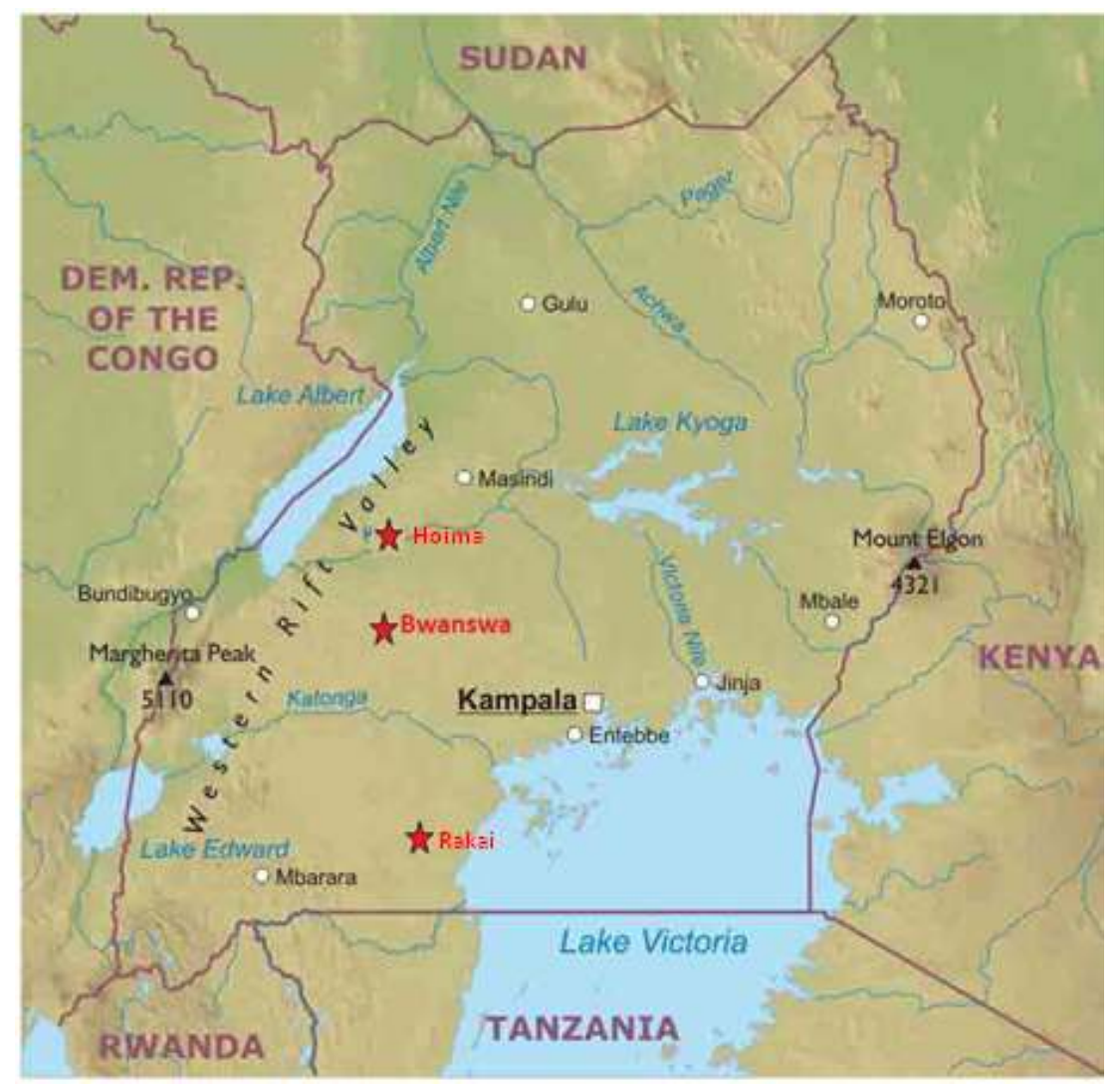

Figure 1.1 Location of Bwanswa sub-county within the country of Uganda (adapted from FreeWorldMaps.net)

Irish Aid drilled a number of deeper wells $(25-70 \mathrm{~m})$ in this area in 2003. Shortly after the wells were constructed, the users began noticing that the first 50-150 liters of water pumped each day were reddish in color. The subsequent water seemed clearer, although if this water was left to the open air, it eventually turned red. The users also reported that the water became more and more unpalatable. The interval from when these wells were initially developed to when they were abandoned ranged from only 1 month to a few years. In general, the greater the number of people the borehole served, the longer the time period before it was abandoned. The more the well was used, the longer it served the community.

Another seemingly related issue was the high rate of corrosion that many of these wells were experiencing. The galvanized iron riser pipes and connecting rods were corroding quickly, resulting in frequent pump failures. The village of Kanyawawa, for example, has needed to replace its riser pipes 6 times since the well was installed 8 years ago, because they were consistently rupturing due to corrosion. Under normal circumstances, these pipes should last for at least a decade or two. 
Visual observation of these wells gave a few clues as to potential factors that might be contributing to the problem. After the water was pumped and allowed to sit for a short while, an oily sheen appeared on the surface, almost as if there were a petroleum product in the water. The pipes of these wells also had some unique characteristics. Some of the pipes were covered in a black slime and smelled of rotten eggs. Other wells had pipes that were covered in a thick orange slime. Most of the pipes and rods suffered from a pitting form of corrosion.

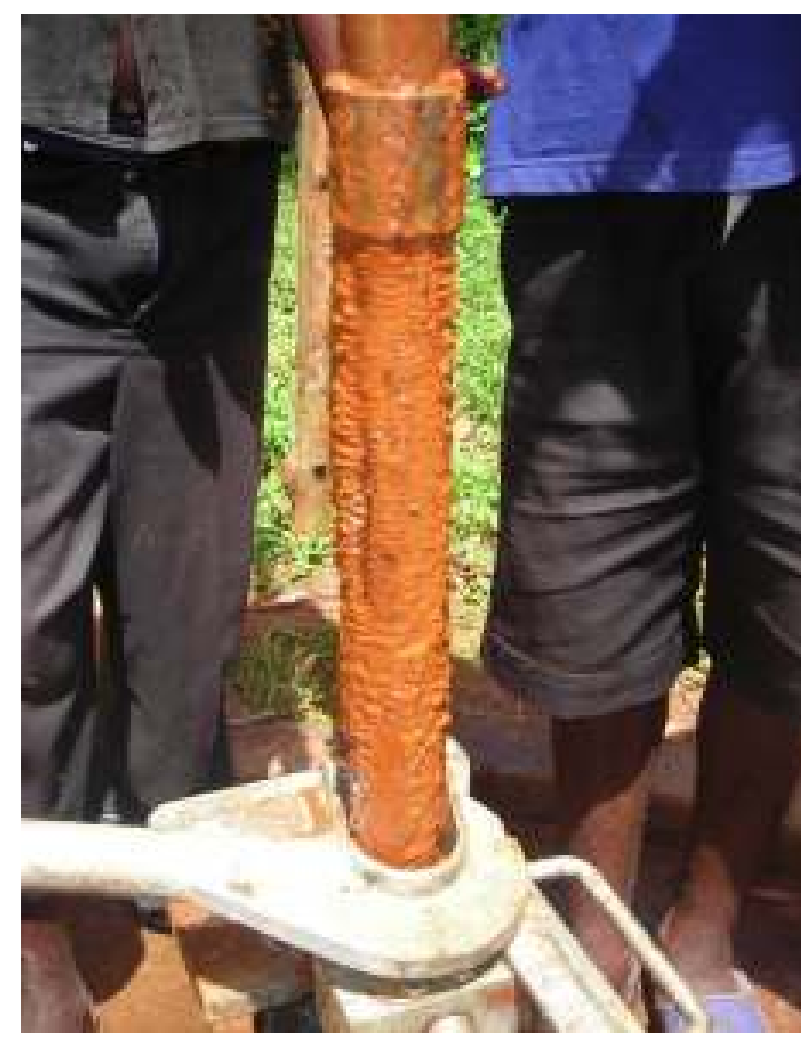

Figure 1.2 Orange slime found on galvanized iron riser pipes extracted from the well in Bulegete (photograph by author)

Another issue in this region was the number of boreholes languishing in disrepair. The problems with most of these wells had never been diagnosed. The wells had simply been abandoned upon mechanical failure. It became evident that the underlying issue here had more to do with the social structures than with actual hardware failure. 


\subsection{Objectives}

The goal of this project was to retrofit the unused boreholes in the Bwanswa region to once again produce clean water. The objectives for meeting this goal were to:

Objective 1: Investigate the causes of poor quality water in the drilled water wells.

Objective 2: Develop a sustainable solution to improve the water sources in response to the cause of contamination.

Objective 3: Work with the communities in a way that empowers them to maintain the quality of their own water sources. 


\section{BACKGROUND}

\subsection{Rural Water Supply and Sanitation Program}

The government of Uganda has established policies for the promulgation of improved water sources into the rural areas of Uganda under the Rural Water Supply and Sanitation Program (RWSSP). The policy states that the government will provide a majority of the initial capital investment for an appropriate improved water system. The type of improved water system depends on the population and environment of the area in need. The various interventions given in order of priority based on affordability and suitability to the location are as follows: spring protection, shallow hand-dug well with a hand pump, gravity fed scheme, borehole, and finally, a centralized piped system (ADF 2005). The government has opted for the use of boreholes in $80 \%$ of rural situations due to their resistance to seasonal variability and contamination (DWD and Danida 2002). The government estimates that a single borehole can serve up to 300 people, and thus, several boreholes may be required to supply a small town. A town with a population greater than 2000 residents is provided with a centralized water system (ADF 2005).

A community is required to fulfill certain criteria before they receive funding for an improved water source. Women must constitute $50 \%$ of the elected Water User Committee, which will be responsible for the maintenance of the water source. A community is also required to increase their household latrine coverage by $30 \%$. Finally, a community must raise a contribution of $2-5 \%$ of the capital costs, amounting to about US $\$ 100$ to $\$ 500$, for the improved water source (ADF 2005). After the water source is installed, the community, represented by the Water User Committee (WUC), is fully responsible for the maintenance of that source. Once the government constructs it, the community is responsible to keep it functioning.

The Rural Water Supply and Sanitation Program has experienced shortcomings in the area of maintenance that has resulted in far too many boreholes in the country languishing in disrepair. The program's community participation requirements, in the three areas stated above, are designed to create a sense of community ownership. However, too often a WUC is appointed by the community leader rather than elected by the people, making it a political opportunity instead of individuals being entrusted with organizing the maintenance of the water source. The latrine coverage figure is easy to falsify as it requires a lot of man-power and effort on the part of the government to verify. The community contribution requirement is so low that many times an aspiring politician or local business man simply pays the amount in full. As result of by-passing the community's involvement in these three areas, the community as a whole has very little buy-in toward the impending water source. 
A community water source will eventually fail and remain in disrepair if a community feels little or no ownership towards the source. The water source is often viewed by the community as a gift given by the government and thus communities often believe that it is the government's responsibility to repair a failing water source. Members of the community who had little or no input in the effort feel no responsibility to maintain it. Thus the wells are often broken and unused for years as the community waits for the government to return to repair their well.

The government of Uganda has a program that trains two local tradesmen in pump maintenance and repair for each sub-county in the country. While this plan for sustainability is a good idea, it has experienced some shortcomings in practice. Many communities do not know that such expertise exists in their sub-county due to a failure of communication. Also some pump mechanics have taken advantage of communities by charging exorbitant amounts for simple repairs. This dishonesty has intimidated other villages into completely foregoing repairs on their water sources.

\subsection{India Mark II Hand Pump}

The India Mark II hand pumps (U2) are the most commonly used pump in the rural areas of Uganda for harvesting groundwater. The U2 system maintains a good track record for durability (S.K. Industries 2008). Spare parts are readily available in larger towns. The India Mark II employs galvanized iron rods for raising/lowering the plunger and galvanized iron riser pipes for conveying the pumped water at depth to the surface. Under normal conditions, the only parts that should need periodic replacement, every 2-5 years depending on use, are the rubber seals and buckets in the cylinder assembly. This requires some technical know-how and specialized tools. Communities are encouraged to allow only trained technicians to do this

maintenance due to the risk of dropping the pipes inside the borehole or further damaging pump components. 


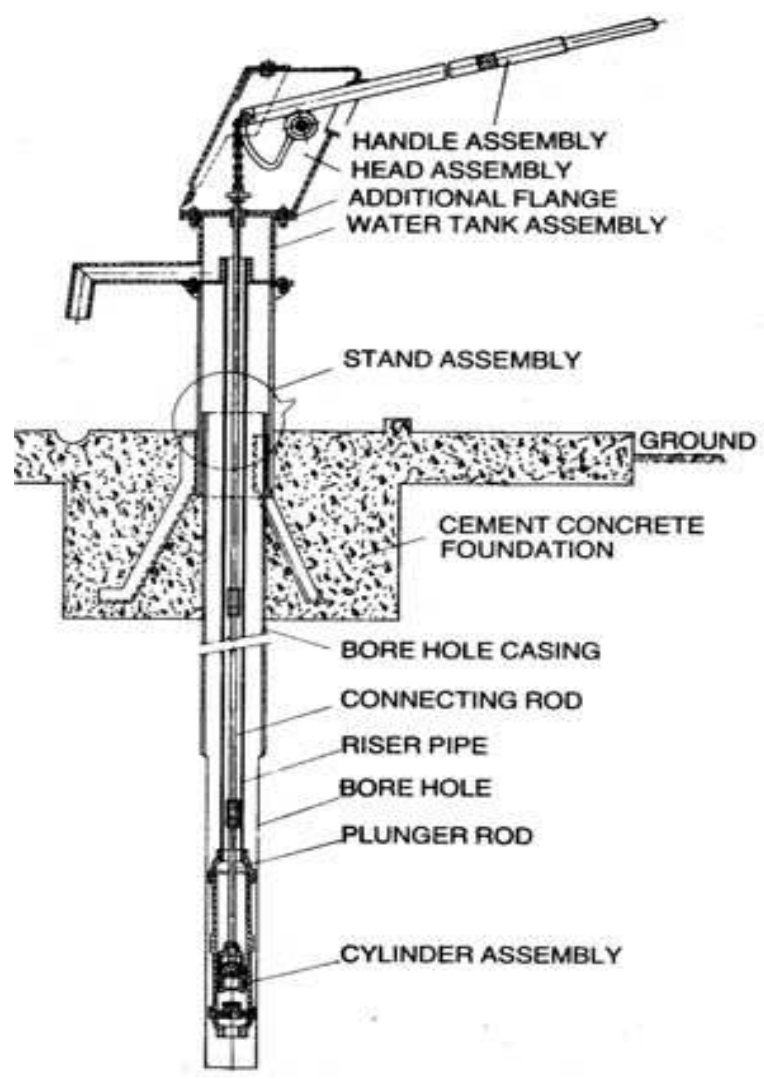

Figure 2.1 Diagram of the India Mark II hand-pump (skipumps.com)

\subsection{Geology}

Under the vast majority of Uganda lies a pre-Cambrian crystalline basement complex (WWAP 2006). In Bwanswa a regolith about 20-30 meters thick overlies this granite bedrock. According to the drilling logs shown in Appendix D, this overburden is generally divided into two parts: a 1-12 meter thick top layer of a loamy soil with laterite, and a lower layer of clay about 10-18 meters thick. 


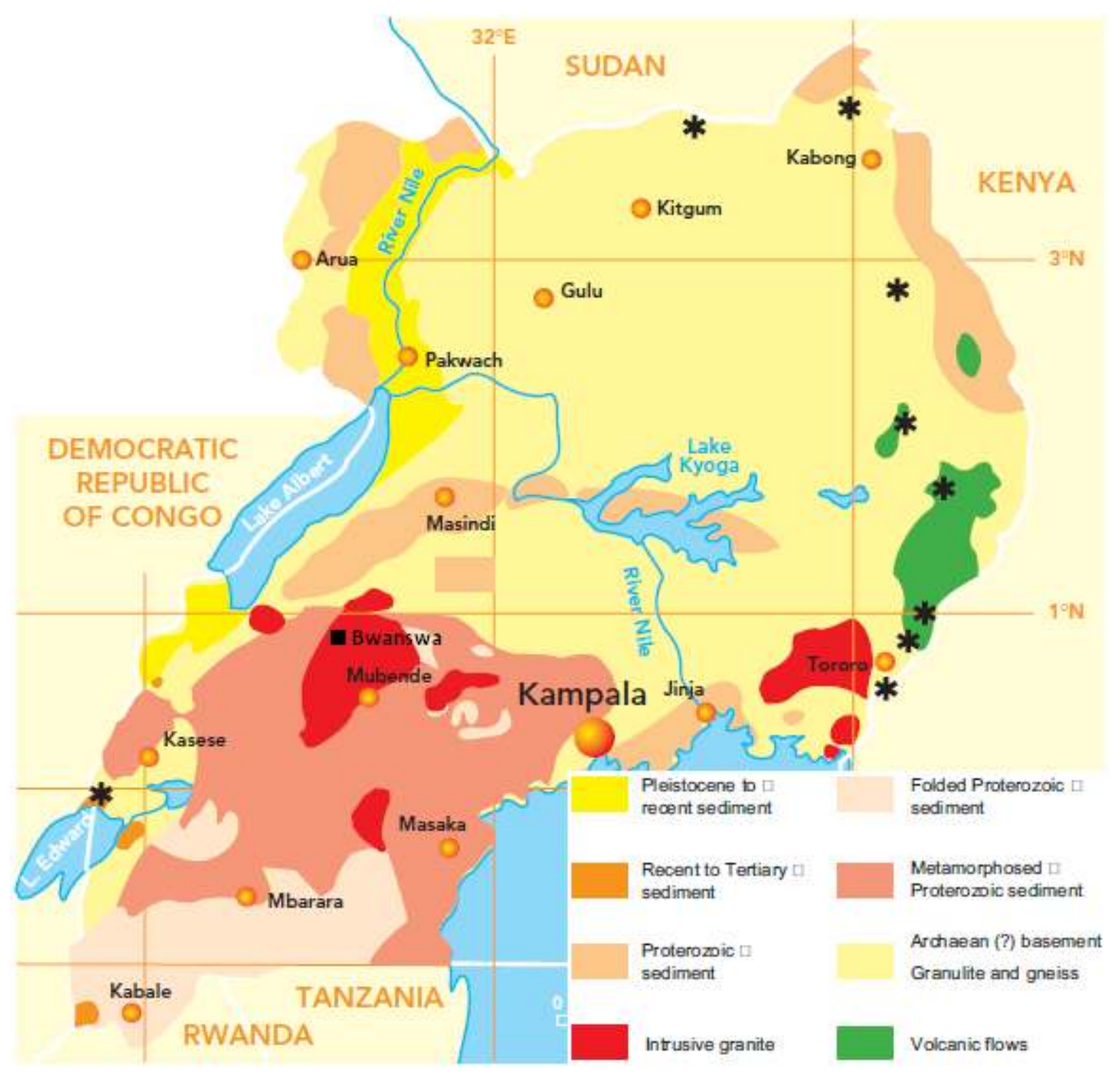

Figure 2.2 Basic geology of Uganda (Adapted from the Government of Uganda 2006)

Traditionally, bedrock wells like those in Bwanswa are not screened, but rather the casing is fixed directly into the bedrock. Wells completed in unconsolidated sediments require well screens to keep the sediments out of the well. The static water level in the Bwanswa boreholes rests above the bedrock in most cases. Therefore, if no screen were installed, the water would have to travel through fractures in the bedrock in order to get into the borehole. With the limited data available, it seems that most often the casing does extend down to the bedrock. 


\subsection{Iron Contamination}

The belt of districts from Rakai, in the far south, to Hoima, which is just north of Bwanswa (see Figure 1.1), all share the same experience with the deterioration of water quality from deep wells configured as in Figure 2.1. The common testimony of people living in these districts is that the water produced by these boreholes is usually reddish/yellowish in color (Figure 2.3), tastes "sour", discolors clothes and food, and soap will not produce lather for washing. These symptoms suggest the presence of dissolved iron. Hand-dug shallow wells $(3-10 \mathrm{~m})$ in this area do not exhibit these same symptoms.

The World Health Organization sets the guideline for the maximum iron content in drinking water at $0.3 \mathrm{mg} / \mathrm{L}$ (WHO 2006). Some of the wells tested in the area were in the $10-25 \mathrm{mg} / \mathrm{L}$ range, with one even reaching $40 \mathrm{mg} / \mathrm{L}$.

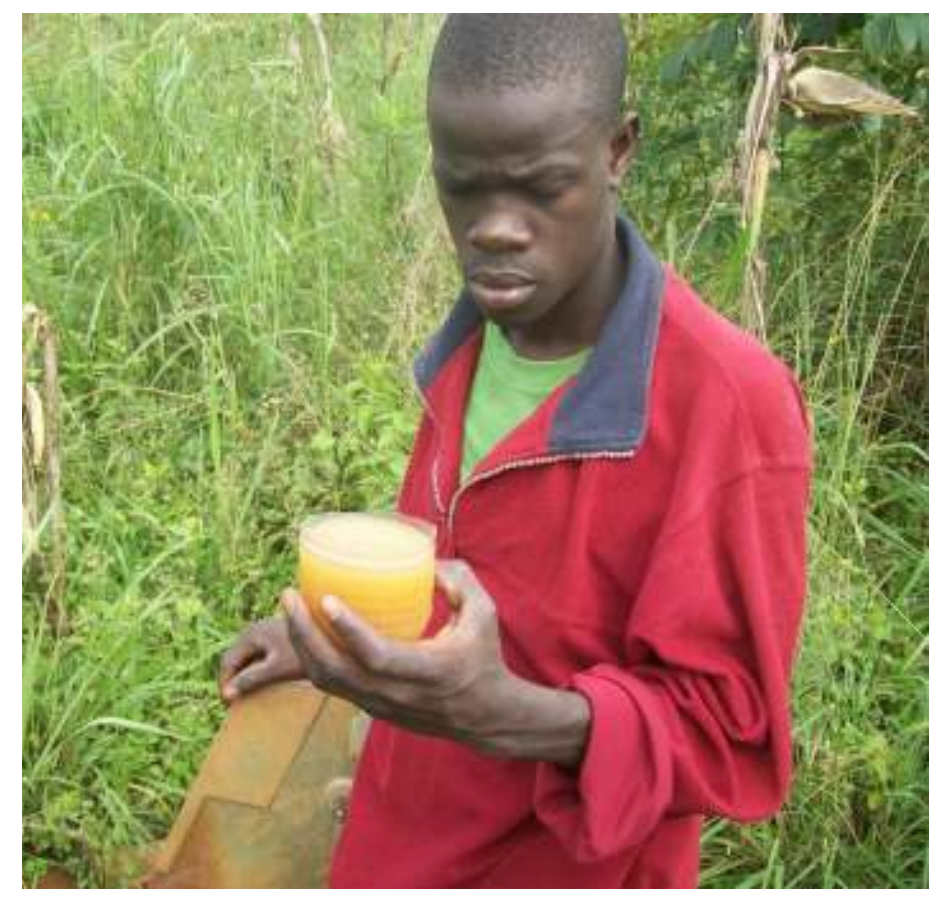

Figure 2.3 Bujune Aloysius reflects on the iron-rich water he just drew from the Kigoli borehole (photograph by author)

Consuming excessive iron does not pose an immediate health threat. Excessive iron does, however, make water unpalatable and thus results in the abandonment of the source and the return to traditional, unprotected sources. These traditional sources are usually small springs that are dammed to form small pools (Figure 2.4), which are highly susceptible to contamination and create potential breeding grounds for mosquitoes. 


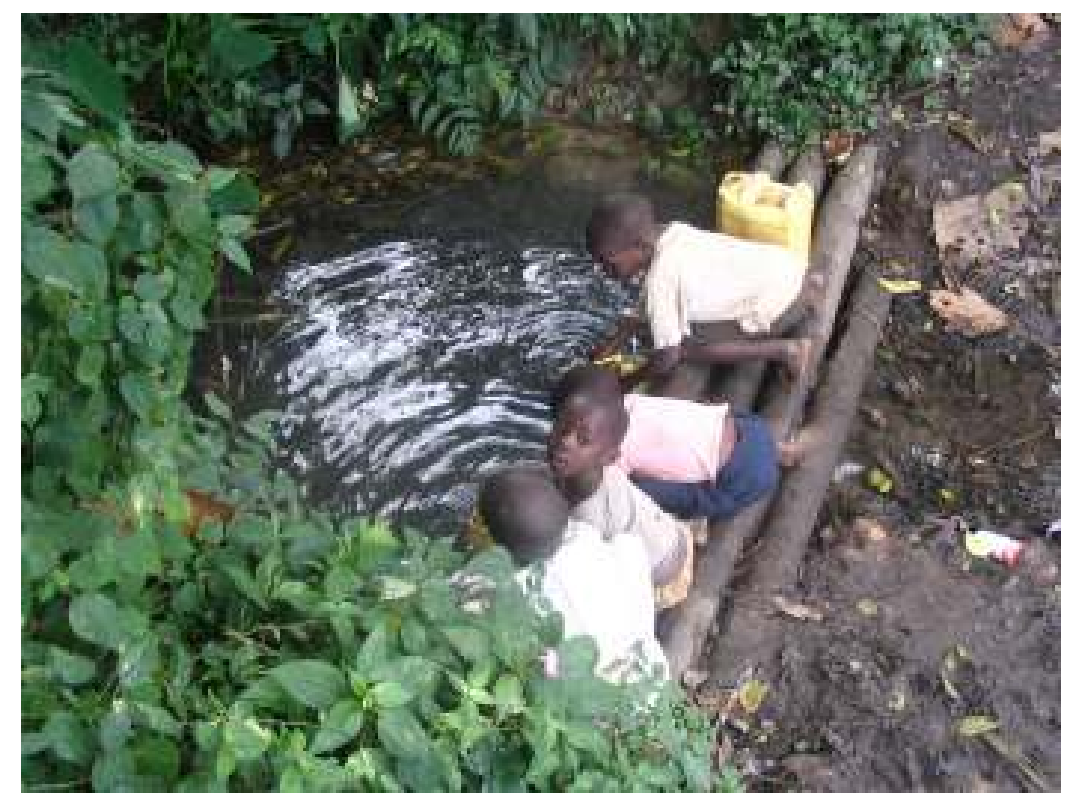

Figure 2.4 Children fetching water from a traditional unprotected spring (photograph by author)

A study conducted by UNICEF and the World Health Organisation (WHO) in Bangladesh found that instances of diarrhoeal diseases were $54 \%$ higher in areas with iron contamination (Ahmed and Smith 1987). The logical conclusion is that, even though an area may have improved water sources, people are not using them due to the unpalatable water, and thus suffer the consequences.

The usage of the water from these boreholes was generally related to the iron levels. Boreholes producing water with iron levels greater than $10 \mathrm{mg} / \mathrm{L}$ were either completely abandoned or only used for domestic duties or watering cattle. In one community, the people were still drinking water with a $3.5 \mathrm{mg} / \mathrm{L}$ iron concentration. This, of course, has a lot to do with the taste tolerance of the community and the unavailability of alternate water sources. This is significant when determining the necessity of an intervention. If a community still consumes their water, even though it has iron levels higher than the WHO standard, then no intervention may be needed.

\subsubsection{Source of the Iron}

The design of an appropriate intervention is contingent upon the source of the iron contaminating the water in these wells. Iron could be coming from the geologic formation surrounding the well, in which case an iron removal system would need to be implemented, and/or it could be coming from the iron components of the well and pump. 
Investigation suggests that the iron was not coming from formation, at least not at the outset, according to the initial chemical analysis reports (Table 2.1). This analysis is required by law and done by the Water Resources Monitoring and Assessment Department at the time of construction of a new water source to verify that the water is safe for consumption. All of the iron content values of the wells in our area were between $0.01-0.45 \mathrm{mg} / \mathrm{L}$, with most of them below $0.1 \mathrm{mg} / \mathrm{L}$. In 2003, these wells were commissioned and deemed safe for consumption as their iron values were acceptable. However, only a few months later, many were abandoned due to the unpalatable water they produced.

Table 2.1 Total iron levels at the time of well construction

\begin{tabular}{lc}
\hline Location & $(\mathbf{m g} / \mathbf{L})$ \\
\hline Kigoli & 0.01 \\
Bulegete & 0.34 \\
Kihurumba & 0.45 \\
Kikonge & 0.12 \\
Nyamacumu & 0.01 \\
Kasojo & 0.06 \\
Kanyawawa & 0.01
\end{tabular}

One might argue that the iron-laden water was being drawn from a different part of the aquifer, thus explaining the initial low iron levels giving way to higher levels as time passed. In some areas of the country this likelihood should be considered. However, the fact that all of the wells in our area initially produced water with low iron levels suggests that no such contaminated aquifer exists.

If a significant portion of the iron was not coming from the geologic formation, then likely its origins are the iron components of the pump itself. Most of the wells in the area suffered from rapid rates of corrosion, and thus the by-products of this corrosion could be contaminating the water.

\subsubsection{Current Interventions in Uganda}

The lead water engineer at the Ministry of Water and Environment in charge of all rural water development in Uganda has experimented with a solution to the iron issue in other areas of the country. He believed that a majority of the iron contamination originated in the geologic formations and hence required a system to remove iron from the water as it is pumped. Working with university students from the United Kingdom, he developed the Silsoe Iron Removal Plant (IRP, see Figure 2.5), which could be retrofitted onto existing boreholes. It consists of an aluminum aeration tray followed by a slow sand filter. In a few pilot projects the 
filter performed sufficiently, although not consistently, removing approximately $90 \%$ of the iron (Kaciel 2004).

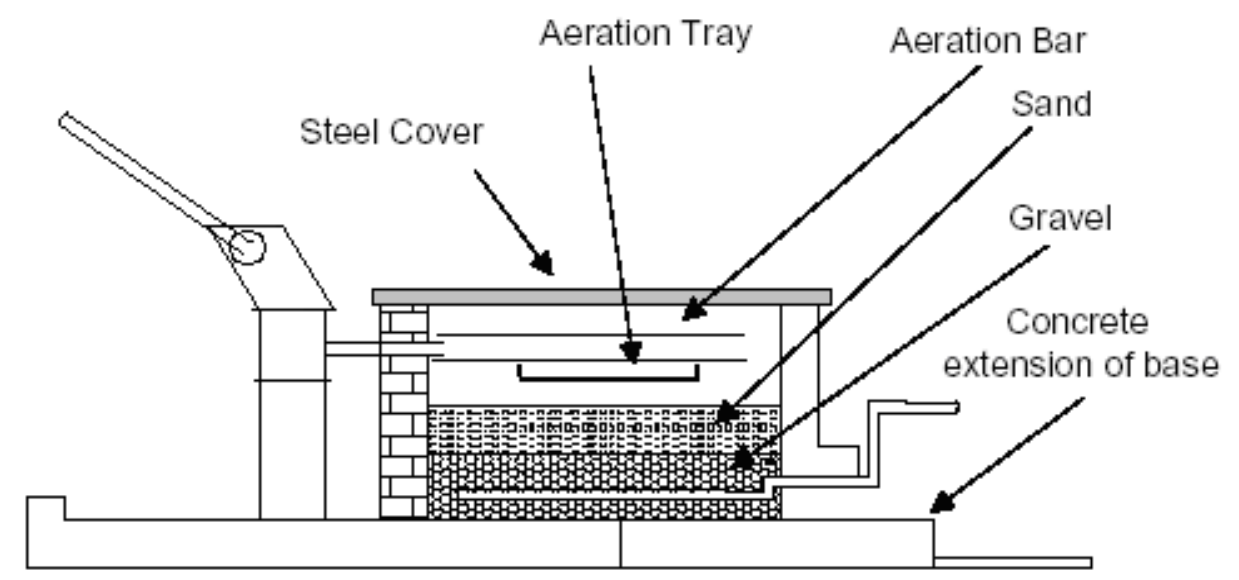

Figure 2.5 Schematic profile of iron removal plants being retrofitted onto India Mark II hand pumps in Uganda (Graphic by Ahmed Sentumbwe)

The Silsoe Iron Removal Plant experienced widespread difficulties over time due to the lack of maintenance performed by the communities. The training given to the water user committees instructed them on the need for and method of cleaning the sand every 2 to 4 weeks. Some communities failed to clean these IRPs even a single time and eventually abandoned the source when the flow reduced to almost nothing. Despite great efforts to foster a sense of ownership and a maintenance schedule, many of these filters failed due to lack of up-keep.

Another intervention is to pour powdered chlorine into the borehole. One Ugandan pump mechanic said he had done this several times with great success. However, this statement may not be completely reliable. He claimed that after chlorination, the well would produce iron-free water for three to five years, but then the effort would have to be repeated. Other pump mechanics had not heard of this method being employed in any other areas of the country.

Another intervention has been implemented by Samaritan's Purse in Western Uganda. Samaritan's Purse, working on the presumption that most community resources in Uganda would shortly meet their demise, decided to implement the use of household bio-sand filters for both disinfection and the removal of iron. No data is available to review the program's effectiveness.

The three interventions mentioned above do not address the corrosion problem in our area and thus would not be satisfactory solutions. Corrosion was certainly an issue that needed to be addressed in addition to iron contamination. 
A final intervention was discovered through observing that the only deep borehole in the immediate area which was not suffering from iron contamination was one installed by a German NGO. This group came through the district within the last decade and drilled boreholes at every primary school. They fitted these wells with high-quality threaded plastic pipe and stainless steel rods from Germany. The borehole at Kitanda Primary School had an iron value of $0.27 \mathrm{mg} / \mathrm{L}$. Although the plastic piping may not have been intended to be an intervention to prevent iron contamination, it was, nonetheless, a desirable outcome.

\subsection{Iron Related Bacteria}

The presence of iron related bacteria (IRB) was suspected due to the orange slime observed on the pipes, in addition to the pump mechanic's comment about chlorination. IRB speed up thermodynamically slow reactions and are a nuisance because of their corrosive behavior (MWH 2005). They utilize inorganic iron in their metabolic processes and thus can vastly increase corrosion rates of iron components in a well (Misstear et al. 2006). IRB are also known to spoil the quality of groundwater sources through releasing their by-products into the water. Under the umbrella term of iron related bacteria are both iron oxidizing bacteria and iron reducing bacteria. IRB produce an orange slime on iron surfaces which causes biofouling of well screens and other components. Wells with IRB can also produce water with an oily sheen on its surface (Tyrrel et al. 1997).

Iron related bacteria originate either from the surrounding soil or from contaminated drill components or tools used during construction or maintenance. After contamination by IRB, there is no solution for permanently eradicating them from a borehole. Most solutions entail simply dosing the well with a strong oxidant, such as chlorine, to kill off the bacteria. However, this effort would have to be periodically repeated as seldom are all of the bacteria destroyed and they will inevitably repopulate (AWWDA 2010).

\subsection{Sulphate Reducing Bacteria}

Black slime and the presence of the hydrogen sulfide (rotten egg) smell in some the wells suggested the presence of sulphate reducing bacteria (SRB). SRB are non-pathogenic, anaerobic bacteria that are capable of causing severe corrosion of iron material (Yuzwa 1991). It is SRB which are most often associated with microbially induced corrosion (Cullimore 1993).

Identifying the presence of sulphate reducing bacteria (SRB) through the use of bacteriological tests is a difficult task. SRB grow in protected areas that are often surrounded by other types of bacteria that could mask their presence (Cullimore 1993). Thus the better way to identify the presence of SRB is to take notice of their distinguishing evidence: rotten-egg smell $\left(\mathrm{H}_{2} \mathrm{~S}\right.$ 
gas), tubercles and corrosion, and black slimes (Cullimore 1993). The presence of $\mathrm{H}_{2} \mathrm{~S}$ gas is of concern because it triggers a series of complex electrolytic corrosion processes on the surface of metal components (Cullimore 1993). The black slime covering the pipes is a metallic sulfide which is a product of hydrogen sulfide reacting to large amounts of metallic materials in the water such as iron or manganese (Cullimore 1993). SRB are controlled in the same way as IRB. As they cannot be completely and permanently eradicated, periodic dosing of the well with a strong oxidant is necessary.

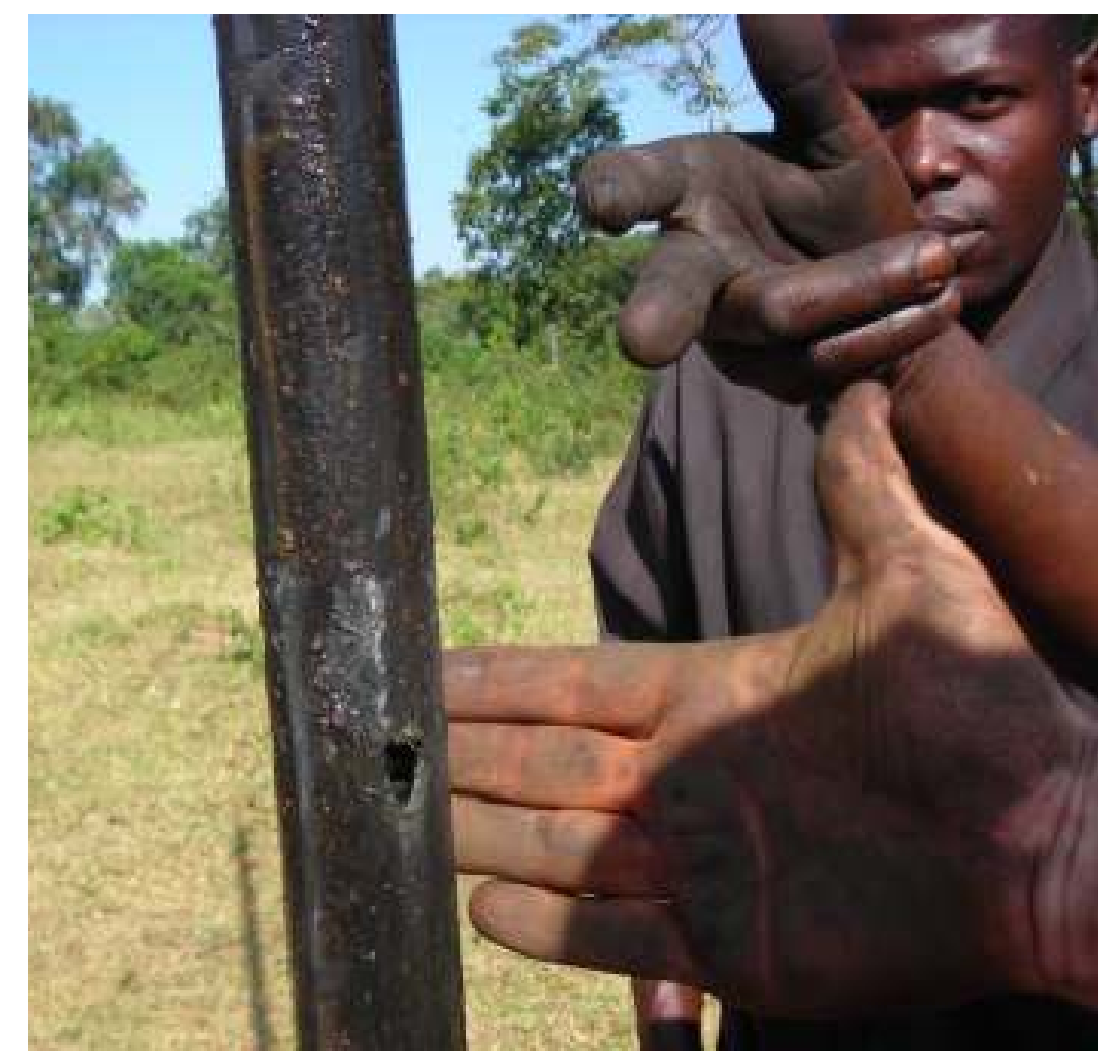

Figure 2.6 A hole eaten into an iron riser pipe from the Kyabasaija well (photograph by author)

This hydrogen sulfide $\left(\mathrm{H}_{2} \mathrm{~S}\right)$ may have a source other than, or in addition to, the SRB. The topography of the area consists of rolling hills with exposed granite tops rising above marshy valleys. These marshes are often stagnant and full of decaying organic material, which, in anoxic conditions, releases a hydrogen sulfide by-product (MWH, 2005). It may be possible that over time these wells could draw the hydrogen sulfide laden water into its bore from these swamps. This would again induce corrosion.

An estimation of groundwater velocity in the area surrounding the well in Kigoli is detailed in Appendix E. This calculation shows that the time needed for hydrogen sulfide laden water to 
travel from the nearest marsh to the borehole would be at least 1500 years. However, since the aquifer in question is composed of fractured granite bedrock, then it might be possible that due preferential paths of flow the real time required could be just a fraction of this calculated time. Since very little is known about the physical properties of this aquifer it would be difficult to build a solid hypothesis on these facts without further investigation. 


\section{METHODS}

For the remedy to be sustainable, it is vital to address both the ownership issue as well as the iron contamination problem. All systems eventually break down, and without a mechanism for maintenance, the benefits of the effort will be short lived. An effective solution requiring frequent and skilled maintenance would result in failure.

\subsection{Community Ownership}

A solid engineering solution alone is not suitable for solving many of Africa's greatest challenges. There is an essential social component that must accompany all technical projects for any lasting effect to be sustained. These social dynamics are difficult but they determine the sustainability of project. While it is beyond the scope of this report to discuss this subject at length, insights into the issues surrounding development work and the promotion of ownership in this region of Uganda can be found in Appendices A and B.

\subsection{Proposed Solution to Iron Contamination}

The proposed solution employed for the iron contamination was to convert these wells from the India Mark II (U2) to the India Mark III-modified (U3M) system coupled with a thorough disinfection of the well with chlorine. Through a grant funded by the President's Emergency Plan For AIDS Relief (PEPFAR), instituted by the former U.S. President George W. Bush, we were able to convert 5 wells to the U3M system in an effort to find a more sustainable solution to remedy iron contamination.

The wells to be converted were chosen based on location, need, and community participation. The wells had to be located within the catchment area mandated by KVDP, the organization with which I was assigned to work. Communities with other available improved water sources were given a lower priority than those without such alternatives. In addition to this, we required full community participation; we would only work with communities who put forth a strong effort to work with us.

The U2 system has long been the most popular setup used in Uganda. It uses the 3-cm (1.25inch) galvanized iron riser pipes in conjunction with galvanized iron rods (Figure 2.1). The U3M setup uses 6.3-cm (2.5-inch) PVC riser pipes and stainless steel rods connected to a brass-lined plastic pumping cylinder. All pipes and rods are a standard 3-m (10-foot) length. The two systems share components such as the handle, head, and pedestal. These parts can be salvaged from a $\mathrm{U} 2$ pump and used in the conversion to a U3M. The main components 
changed were the pipes, pumping cylinder, rods, and water tank. The conversion from U2 to U3M usually takes one day, with the help of community volunteers ( Figure 3.1) and costs between US $\$ 400$ and $\$ 850$ depending on the depth required. Table 3.1 shows the cost for a 15-pipe-length conversion. This is the deepest recommended depth that PVC should be used due to its tensile strength limitations.

Table 3.1 Itemized list of parts needed for a U2 to U3M conversion. Prices given by Multiple Industries Limited, Kampala, Uganda in 2010.

\begin{tabular}{lcccc}
\hline Item & Quantity & Unit & Rate (UGX) & Total (UGX) \\
\hline Stainless Rods & 15 & Piece & 63,750 & 956,250 \\
PVC Pipes & 15 & Piece & 27,200 & 408,000 \\
U3m Cylinder & 1 & Piece & 127,500 & 127,500 \\
U3m Water Tank & 1 & Piece & 102,000 & 102,000 \\
Rod Centralizers & 15 & Piece & 935 & 14,025 \\
Pipe Centralizers & 8 & Piece & 1,360 & 10,880 \\
Nylon Rope & 1 & Length & 14,365 & 14,365 \\
Con Seat Plate & 1 & Piece & 36,700 & 36,700 \\
Solvent Cement & 1 & Piece & 10,200 & 10,200 \\
Rubber Con Seat & 1 & Piece & 15,000 & 15,000 \\
Top Sleeve & 1 & Piece & 1,700 & 1,700 \\
& & & & $1,696,620$ \\
\cline { 3 - 4 } & & & Total (UGX) & $\$ 848.31$ \\
\cline { 3 - 4 } & & & &
\end{tabular}

Four of the five converted boreholes were also chlorinated before the community was permitted to use the water. Some literature states that a concentration of at least 200 ppm of chlorine inside the well is required to sufficiently disinfect boreholes with an iron bacteria problem (AWWDA 2010), whereas other sources say that at least $1000 \mathrm{ppm}$ is needed (MCCHD 2010). To split the difference, a concentration of approximately 500 ppm was prepared in these boreholes for a 24 hour period. This was done by adding approximately 16.0 grams of chlorine powder (Calcium Hypochlorite with $65 \%$ available chlorine) for every meter of submerged borehole of $115-\mathrm{mm}$ (4.5-inch) diameter, and 28.9 grams for each meter of the $150-\mathrm{mm}$ (6-inch) diameter borehole. On the day following chlorination members of the community gathered to pump out the chlorine-rich water. The effort usually drew quite a crowd, since we were working on wells that had not produced good water for years. People were curious to see any change in the water quality. Continuous pumping for 2-4 hours at roughly $7 \mathrm{~L} / \mathrm{min}$ gave between $2-10$ well-volume displacements depending on well depth. This 
removed most of the chlorine smell. Generally no smell was detected by the community after a day or two of use.

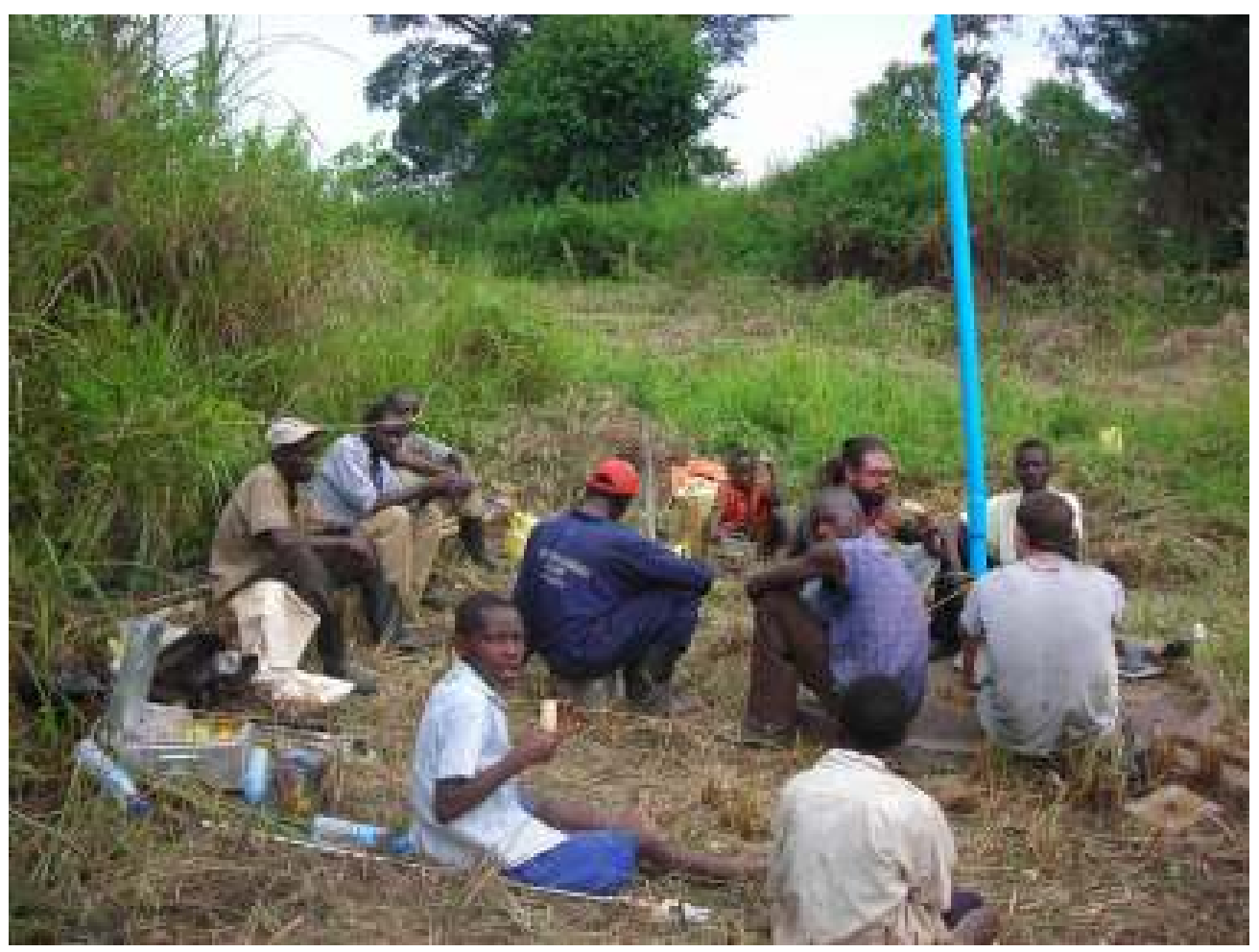

Figure 3.1 Taking a boiled corn break during the borehole conversion at Kihurumba (photograph by author)

\subsubsection{Kigoli}

The well in the community of Kigoli was constructed on June 21, 2003. It produced good water for one month before starting to produce reddish/yellow-colored, iron-rich water (Figure 2.3). It was then completely abandoned. We converted the 10 pipes and chlorinated the well on March 30, 2010. The galvanized iron riser pipes removed from the well were covered in a black slime and smelled of hydrogen sulfide. The driller's log for this well and the following wells can be found in Appendix D.

\subsubsection{Bukumi}

The well at Bukumi was constructed in the 1980s and was fitted with steel casing. It functioned intermittently for more than two decades. Most recently the well was only being used for domestic duties and had fallen into disrepair. The community members made no effort to repair it because in the past few years it had begun producing poor 
quality water. An orange slime covered the submerged galvanized iron riser pipes that were removed from the well. With a new foundation laid and its 15 pipes converted, the well was disinfected on April 5, 2010.

\subsubsection{Bulegete}

The community of Bulegete is unique compared to other villages in the area. Strong community leadership and attention to maintenance had kept their well functioning since its construction in 2003. The iron level in the water was diluted enough, as a result of serving many people, that it was used for all purposes, even drinking. However, the community had grown weary of repairing their well. The pipes ruptured repeatedly, and the rods frequently failed due to extremely high rates of corrosion. We did not chlorinate the well since it was being used at the time of the 6-pipe conversion. The pipes extracted were covered in a thick orange slime (Figure 1.2). This work was completed on May 6, 2010.

\subsubsection{Kihurumba}

This well was drilled in June of 2003. It produced good water for 2 months before it was completely abandoned due to poor water quality. The pipes pulled from this well were covered in a black slime and smelled strongly of hydrogen sulfide. The well was disinfected and the 9 pipes converted on June 19, 2010.

\subsubsection{Kyabasaija}

The well at Kyabasaija church was drilled on June 19, 2003. It functioned for about 5 years until it started producing 'yellowish' water. The pump failed shortly thereafter. The community put forth no effort to fix it because of the unpalatable water it had started to produce. The pipes pulled from this well were black and had obvious instances of localized corrosion as seen in Figure 2.6. Disinfection and a 13-pipe conversion were completed on June 23, 2010. 
Table 3.2 Summary of wells converted and their characteristics

\begin{tabular}{|c|c|c|c|c|c|}
\hline Location & $\begin{array}{c}\text { Date } \\
\text { Drilled }\end{array}$ & $\begin{array}{l}\text { Period of } \\
\text { Use }\end{array}$ & Observations & $\begin{array}{c}\text { Pipes } \\
\text { Converted }\end{array}$ & $\begin{array}{c}\text { Chlorine } \\
\text { Disinfection }\end{array}$ \\
\hline Kigoli & June-03 & 1 month & $\begin{array}{l}\text { Black Pipes, Pitting } \\
\text { Corrosion, Rotten Egg } \\
\text { Odor }\end{array}$ & 30-Mar-10 & Yes \\
\hline Bukumi & $1980 \mathrm{~s}$ & 20 years & $\begin{array}{l}\text { Corrosion, Orange } \\
\text { Slime }\end{array}$ & 5-Apr-10 & Yes \\
\hline Bulegete & June-03 & In use & $\begin{array}{l}\text { Corrosion, Orange } \\
\text { Slime }\end{array}$ & 6-May-10 & No \\
\hline Kihurumba & June-03 & 2 months & $\begin{array}{l}\text { Black Pipes, Corrosion, } \\
\text { Rotten Egg Odor }\end{array}$ & 19-Jun-10 & Yes \\
\hline Kyabasaija & June-03 & 5 years & $\begin{array}{l}\text { Black Pipes, Pitting } \\
\text { Corrosion, Rotten Egg } \\
\text { Odor }\end{array}$ & 23-Jun-10 & Yes \\
\hline
\end{tabular}

\subsection{Chemical and Biological Testing}

\subsubsection{Iron Levels}

Well water samples were collected in plastic water bottles and carried $200 \mathrm{~km}$ to the Water Quality and Pollution Control Laboratory in Entebbe, Uganda. The lab appeared wellequipped, and the staff members were eager to help. Results were returned by way of a professional report called a 'Certificate of Analysis'. A few samples were also sent to the Upper Peninsula Laboratory of the Michigan Department of Community Health in Houghton, Michigan (now closed) to confirm results received from the lab in Entebbe, Uganda.

\subsubsection{IRB-BART ${ }^{\text {TM }}$ Test Kits}

The presence of iron related bacteria was investigated, through the use of Biological Activity Reaction Tests (BART ${ }^{\mathrm{TM}}$ ), as a possible cause for both excessive corrosion as well as high iron content in the water. These test kits are available from the LaMotte Company at www.lamotte.com. The test is intended primarily to function as a presence/absence test, but an approximate bacterial population can be estimated given the number of days before a reaction appears as shown in Table 3.3. 
Table 3.3 Approximate bacterial population in $\mathrm{cfu} / \mathrm{ml}$ as a function of days to reaction as indicated by IRB-BART ${ }^{\mathrm{TM}}$ kits

\begin{tabular}{cc}
\hline Reaction Day & $\begin{array}{c}\text { Approximate IRB } \\
\text { Population }\end{array}$ \\
\hline 2 & 140,000 \\
3 & 50,000 \\
4 & 9,000 \\
5 & 2,300 \\
6 & 500 \\
8 & 25 \\
9 & None
\end{tabular}

The test also can indicate which of the iron related bacteria is dominant in the system. This is done through carefully observing changes in the test tubes over the 9-day test period. Color changes and physical growths are monitored and recorded. A complete description of the 10 reactions and their variations is explained by Cullimore (1993) in his book on groundwater microbiology.

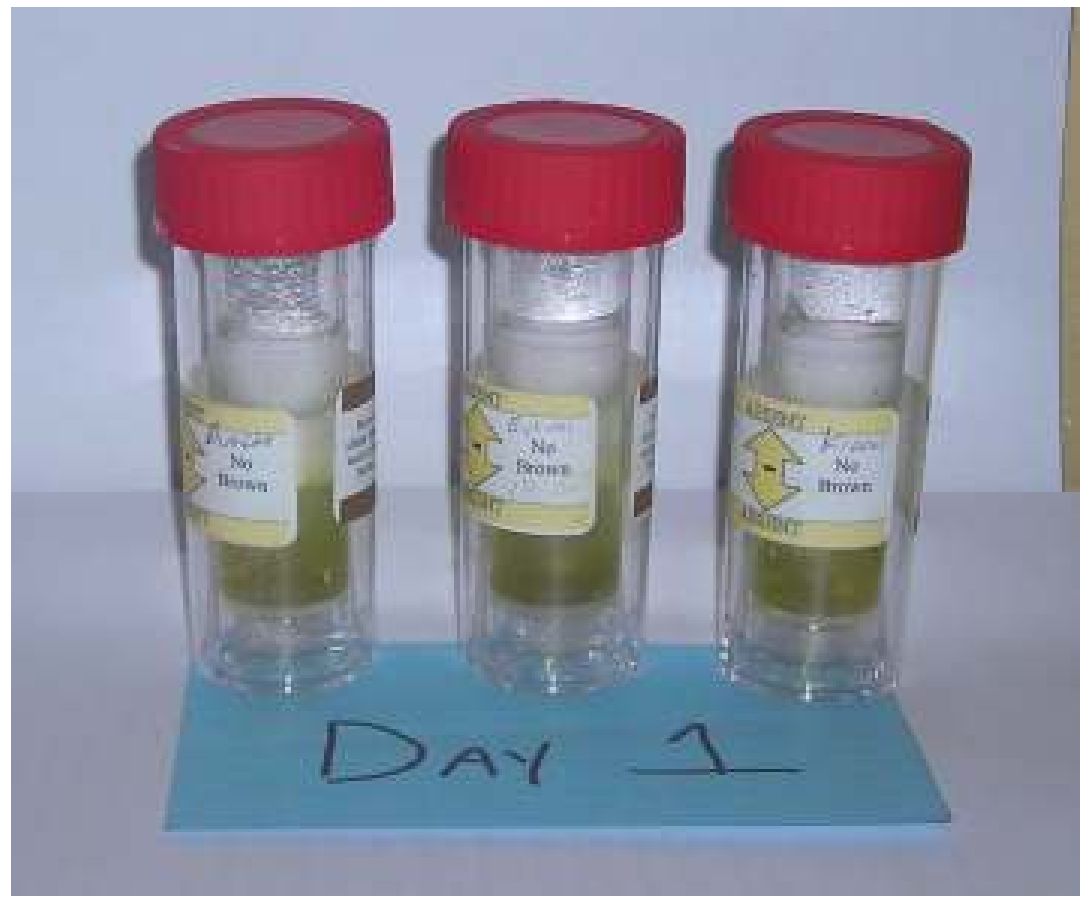

Figure 3.2 First day of testing for IRB using IRB-BART ${ }^{\mathrm{TM}}$ test kits (photograph by author) 
IRB-BART TM $^{\mathrm{TM}}$ test kits are simple to use, whereby a user pours $15 \mathrm{ml}$ of a water sample into the inner test tube which has certain nutrients at the bottom and white plastic ball. It is then placed in the outer test tube for odor control and spill containment. The sample is then incubated at room temperature, out of direct sunlight, for a period of 9 days as the user observes and records changes. Given the infrastructure challenges in Uganda, this serves as a very practical and appropriate test, although slightly expensive (each tube displayed in Figure 3.2 costs about US $\$ 14$ in 2010 , including shipping to Uganda).

\section{$3.3 .3 \mathrm{pH}$}

The sample $\mathrm{pH}$ was measured using a Cole-Parmer 59002-02 pH/mV/Temperature meter. It was calibrated in Houghton, MI before being sent to Uganda.

\subsubsection{Ammonia}

Ammonia concentrations were measured using a Palintest photometer borrowed from the Department of Natural Resources of Mubende District, Uganda. A 10-ml sample of well water was added to a test tube along with 2 solid reagents. After the reagents dissolved, the sample was given time to react. The test tube was then placed in the photometer to measure the percentage of light passing through it, in comparison to a blank test tube. The percentage was then converted to a concentration using the calibration curve provided with the photometer.

\subsubsection{Sulphate}

Sulphate values were measured at the Upper Peninsula Laboratory of the Michigan Department of "Community Health in Houghton, Michigan using method SM 4500 SO4E. This is equivalent to the USEPA method 375.2. This is also called method 10-116-10-3-A which was developed by the Lachat Instrument Company. Lachat Instruments patented this turbidimetric method which they call 'Quikchem Flow Injection Analysis' (Lachat Instruments 2010). The reporting limit for sulphate is $5 \mathrm{mg} / \mathrm{L}$. 


\section{RESULTS AND DISCUSSION}

The results were very encouraging from a practical standpoint. These wells, which were sitting idle for years while the communities drew their drinking water from unprotected sources, are now functioning and producing very clear water (Figure 4.1). A community member from Bukumi commented, "Thank you for your work. Our water now tastes better than Rwenzori (bottled water)!"

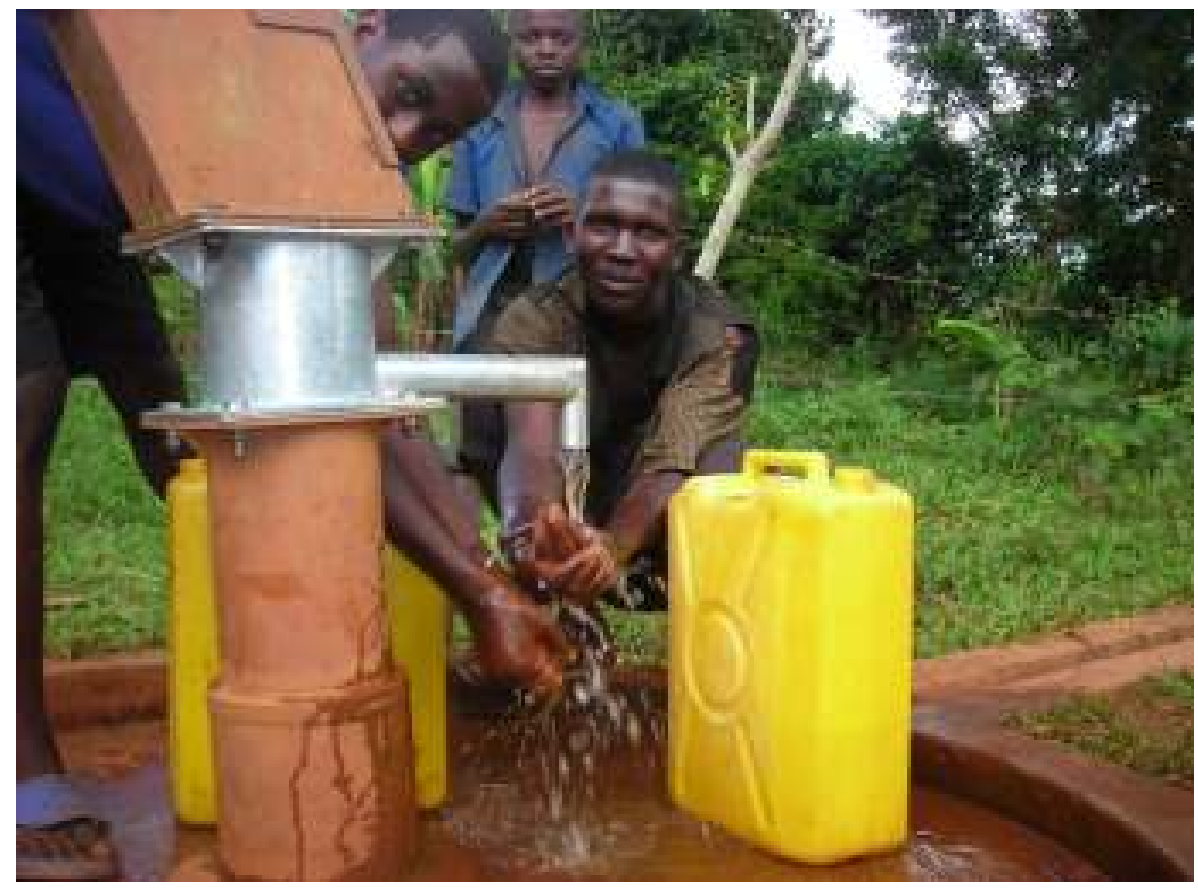

Figure 4.1 Members of the Bulegete community enjoying their restored water source (photograph by author)

\subsection{Iron}

The iron in the water produced by these wells, and so many others in Uganda, is the main reason they were abandoned. The iron levels were brought down to an acceptable level through our intervention. The majority of the results in Table 4.1 were obtained from the Water Quality and Pollution Control Laboratory in Entebbe, Uganda. The Upper Peninsula Laboratory of the Michigan Department of Community Health in Houghton, Michigan reported consistent results, finding that iron was 'not detected' (reporting limit: $0.1 \mathrm{mg} / \mathrm{L}$ ) for samples collected in September of 2010 from Kigoli, Bukumi, and Kyabasaija. These values may be lower than the Ugandan results due to the fact that they were tested 54 days after the 
sample was collected. Iron may have adhered to the walls of the container and/or come out of solution, thus affecting the results.

Table 4.1 Iron levels in mg/L of wells in Bwanswa sub-county tested in Entebbe, Uganda. Starred $\left(^{*}\right)$ column tested in Houghton, MI.

\begin{tabular}{lcccc}
\hline Location & $\mathbf{2 0 0 3}$ & $\mathbf{2 0 0 9}$ & $\mathbf{2 0 1 0}$ & $\mathbf{2 0 1 0} \boldsymbol{}$ \\
\hline Kigoli & 0.01 & 40.63 & 0.06 & 'Not Detected' \\
Bulegete & 0.34 & 2.43 & 0.05 & No Data \\
Bukumi & No Data & 21.63 & 0.39 & 'Not Detected' \\
Kihurumba & 0.45 & No Data & 0.84 & No Data \\
Kyabasaija & No Data & (Pump broken) & 0.61 & 'Not Detected'
\end{tabular}

The data from 2003 shows that these wells did not suffer iron contamination upon their construction. People from Bukumi and Kyabasaija have also stated that their wells produced good water for years before being abandoned. The values from 2009 were taken before implementing the remedy. The iron levels of samples from September 2010 were taken after the intervention. Telephone communication on December 24, 2010, with three individual sources in Uganda confirmed that all five wells were still functioning, and the water is still fully accepted by the communities.

I would guess that if iron content were to be measured again in a few years, all of the wells would have levels closer to their original values, measured in 2003, except for Bukumi. The well at Bukumi was installed in the 1980s, and thus has steel casing which is very difficult and expensive to convert to PVC. The casing provides the iron that IRB need for their respiration. This could foster new colonies and might create the same iron contamination as seen before. Bukumi would be a good case study for the effectiveness of periodic chlorination to control IRB populations.

An inconsistency might exist between the reported geology of the area and the iron values found upon construction. Granite is considered to be iron-poor. As such, since granite would be the parent rock, the regolith too should be iron-poor. However, many of the driller logs say that laterite is present in the regolith. Laterite is a soil that is rich in aluminum and iron hydroxides. Either this soil was misidentified by the drilling team or this lateritic soil originates elsewhere and does not leach its iron into the groundwater. 


\subsection{Iron Related Bacteria}

Most of the wells in our area tested positive for one or more varieties of IRB through the use of Biological Activity Reaction Tests (BART ${ }^{\mathrm{TM}}$ ) for iron related bacteria. The results are listed in Table 4.2 and discussed in the sections that follow.

Table 4.2 Approximate bacterial populations in $\mathrm{cfu} / \mathrm{ml}$ as indicated by IRB-BART ${ }^{\mathrm{TM}}$ kits. $(\mathrm{P})$ indicates plastic riser pipes and (I) indicates galvanized iron riser pipes.

\begin{tabular}{lcccc}
\hline Location & Sample Day & $\begin{array}{c}\text { Anaerobic } \\
\text { Bacteria }\end{array}$ & $\begin{array}{c}\text { Enteric } \\
\text { Bacteria }\end{array}$ & $\begin{array}{c}\text { Pseudo- } \\
\text { monads }\end{array}$ \\
\hline Kigoli (P) & 16-Jun-10 & 9,000 & 0 & 2,300 \\
Kigoli (P) & 12-Aug-10 & 50,000 & 0 & 0 \\
Bulegete (P) & 16-Jun-10 & 9,000 & 0 & 2,300 \\
Bulegete (P) & 12-Aug-10 & 9,000 & 500 & 0 \\
Bukumi (P) & 16-Jun-10 & 9,000 & 500 & 0 \\
Bukumi (P) & 12-Aug-10 & 50,000 & 0 & 0 \\
Kihurumba (I) & 17-Jun-10 & 9,000 & 2,300 & 0 \\
Kihurumba (P) & 12-Aug-10 & 140,000 & 9,000 & 0 \\
Kyabasaija (P) & 12-Aug-10 & 50,000 & 500 & 0 \\
Kasojo PS (I) & 17-Jun-10 & 9,000 & 500 & 0 \\
Kikonge (I) & 12-Aug-10 & 140,000 & 2,300 & 0 \\
Nyamacumu (I) & 12-Aug-10 & 9,000 & 0 & 0 \\
Kanyawawa (I) & 12-Aug-10 & 0 & 0 & 0 \\
Ug. Martyr's (I) & 12-Aug-10 & 140,000 & 0 & 0 \\
Eden (I) & 12-Aug-10 & 140,000 & 500 & 0 \\
St. Edwards (I) & 12-Aug-10 & 140,000 & 0 & 0
\end{tabular}

\subsubsection{Anaerobic Bacteria}

Eleven of twelve wells tested showed a positive reaction for anaerobic bacterial activity. This is referred to as Reaction 5 and is indicated by bubbles or foam appearing under and around the floating ball of the IRB-BART ${ }^{\mathrm{TM}}$ kit as shown in Figure 4.2. The literature states that a correlation potentially exists between Reaction 5 and the presence of sulphate reducing bacteria (Cullimore 1993). 


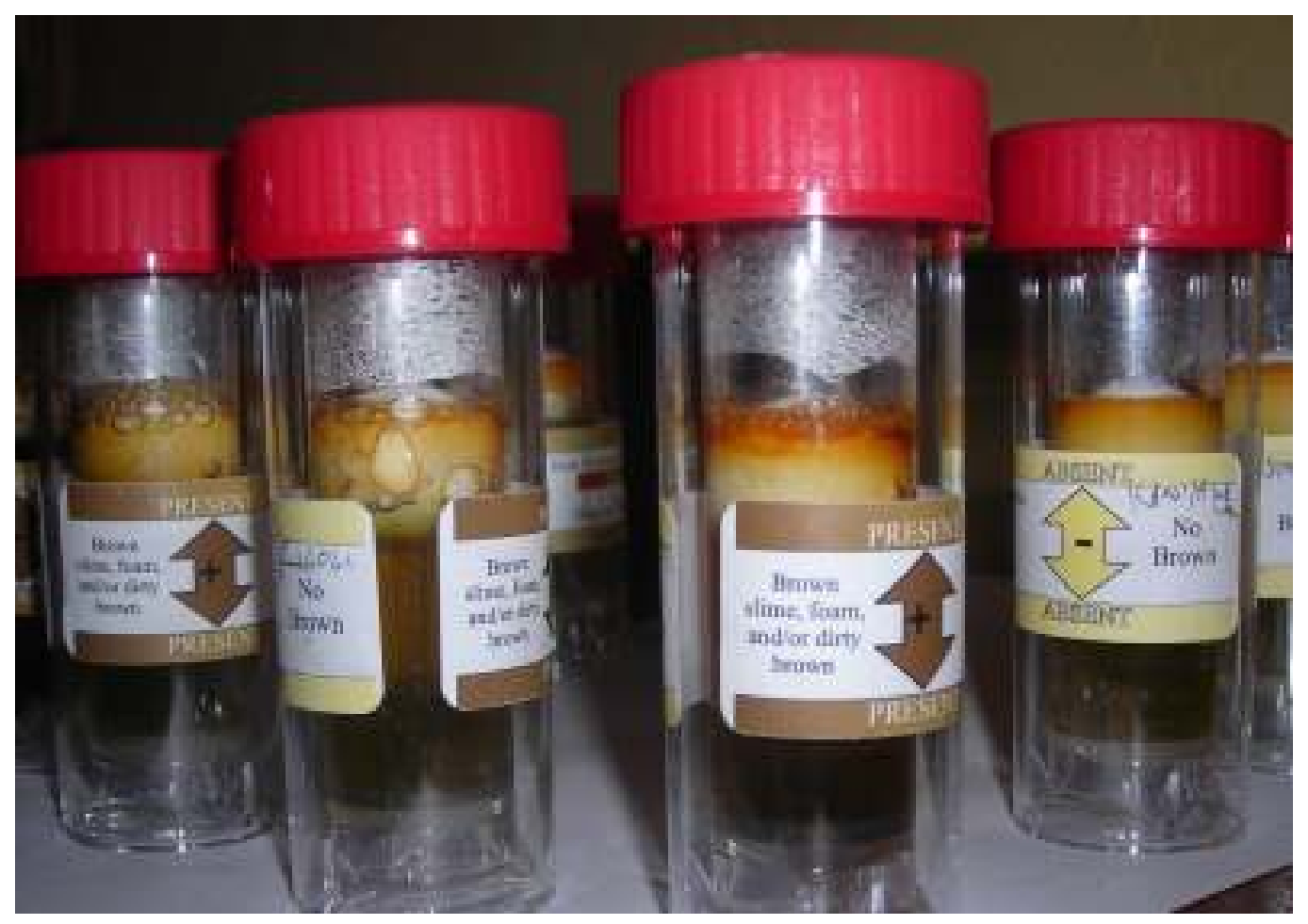

Figure 4.2 From left to right: bubbles appearing in IRB-BART ${ }^{\mathrm{TM}}$ samples taken from Bukumi, Kigoli, and Bulegete. No bubbles in Kanyawawa's sample. (photograph by author)

\subsubsection{Enteric Bacteria}

All of the samples that showed the signs of enteric bacteria did so as a secondary reaction following Reaction 5. The bacteria of a secondary reaction are not as dominant as those of the primary reaction. Enteric bacteria can be indicated by a scarlet red hue, seen in Figure 4.3, which is characterized as Reaction 7. The two major genera of bacteria causing this reaction are klebsiella and enterobacter (Cullimore 1993). Enteric bacteria can also be indicated by a blackening of the sample as shown by Kasojo in Figure 4.3. This is characterized as Reaction 10 , which can also indicate the presence of sulphate reducing bacteria. 


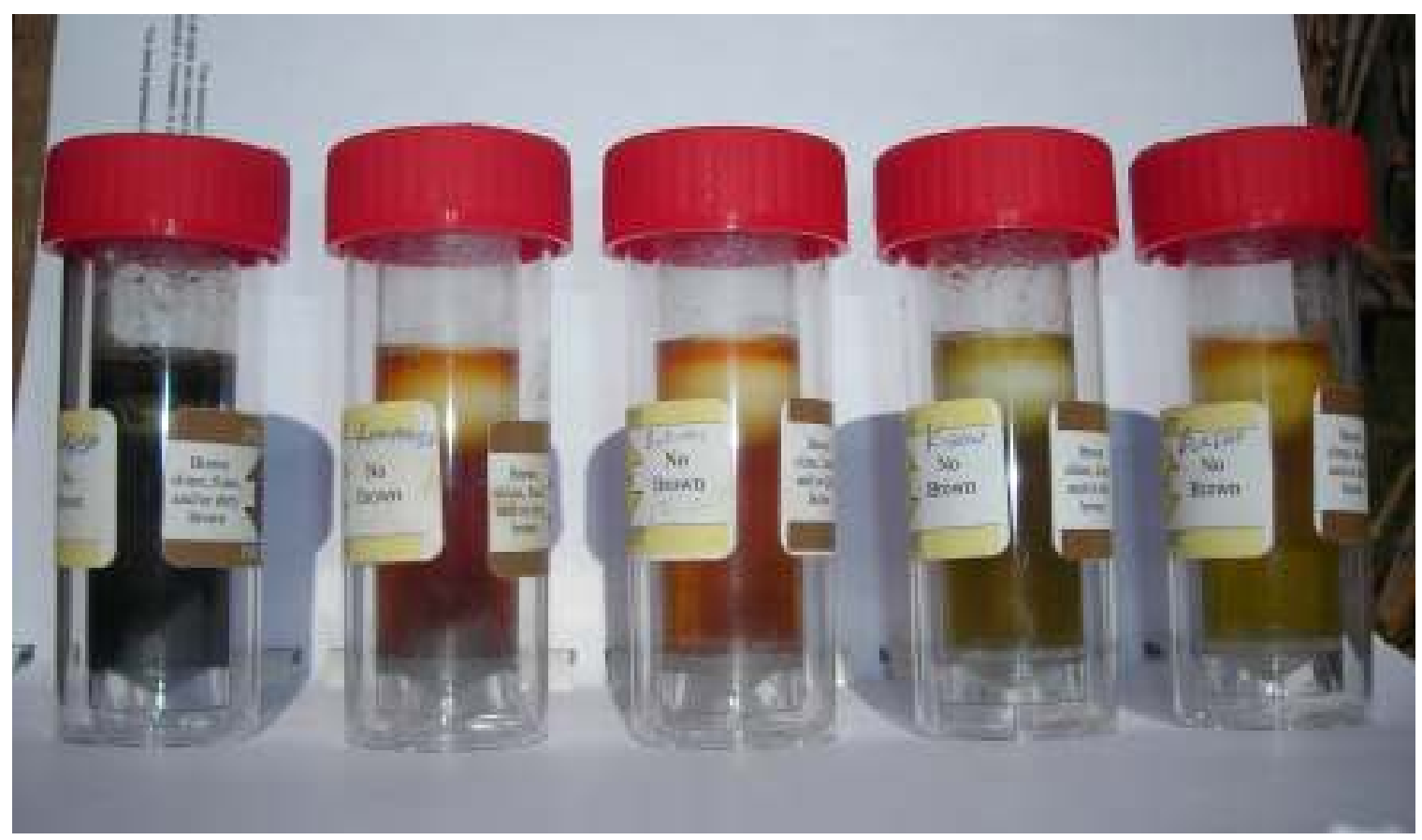

Figure 4.3 From left to right: black reaction from Kasojo, scarlet samples from Kihurumba and Bukumi, and clear green reaction from Kigoli and Bulegete. (photograph by author)

\subsubsection{Pseudomonads}

Only two wells showed Reaction 8, which is described as having a clear green coloration throughout the liquid medium, seen at the right of Figure 4.3. Both Kigoli and Bulegete initially indicated the presence of pseudomonads in June, but when retested two months later neither exhibited this reaction.

\subsubsection{IRB Discussion}

The unique progress of these communities and the importance of following their lead, coupled with the logistics of getting IRB-BART ${ }^{\mathrm{TM}}$ kits to the remote areas in Uganda, led to only one well being tested before and after its conversion to the U3M system: Kihurumba. The other wells could only be tested after they had been converted. These were each tested twice. Interestingly, 3 of the 4 wells tested twice had greater populations of bacteria the second time. The only well in which the IRB population did not increase was Bulegete, which remained the same. Bulegete was also the only well that was not chlorinated as part of this work.

The increase in bacterial population after the component replacements and disinfection is not the issue of greatest concern. The more pertinent matter is that these bacteria, even though still present in great number, do not seem to affect the dissolved iron concentrations. These wells 
have had very low iron concentrations, and complete community acceptance, since the removal of their iron components. Therefore, it seems that efforts should be focused on removing the iron components from the wells, rather than controlling the IRB population.

The rapid return of bacterial populations after disinfection also suggests that disinfection alone would not be a good intervention against iron contamination. However, as with the case of Bulegete, perhaps only a pipe exchange without disinfection constitutes a suitable intervention. This would need to be explored more thoroughly.

\section{$4.3 \mathrm{pH}$}

Evidence has shown a strong correlation between $\mathrm{pH}$ and corrosion. Even $\mathrm{pH}$ values as low as 6.5 can be considered moderately corrosive (Langenegger 1994). The data show that most of the wells in Bwanswa have historically had an acidic $\mathrm{pH}$. In the country of Ivory Coast, Langenegger (1994) found that in two wells with a $\mathrm{pH}$ of 6.0 the zinc galvanizing the iron pipes was completely dissolved within 3-6 months of installation. After the zinc had dissolved, the iron concentrations started to rise.

Interestingly, most of the $\mathrm{pH}$ values have decreased over time. SRB can cause the $\mathrm{pH}$ of some water sources to fall to as low as 5.0 (Yuzwa 1991) through the production of organic acids and hydrochloric acid (Tyrrel et al. 1997).

Table $4.3 \mathrm{pH}$ values over time. Starred $\left(^{*}\right)$ values were measured after pipe conversion and disinfection (except no disinfection at Bulegete)

\begin{tabular}{lcc}
\hline Location & $\mathbf{2 0 0 3}$ & $\mathbf{2 0 1 0}$ \\
\hline Kigoli & 6.70 & $5.72^{*}$ \\
Bulegete & 6.60 & $5.41^{*}$ \\
Kihurumba & 7.60 & $5.73^{*}$ \\
Kyabasaija & - & $5.51^{*}$ \\
Bukumi & - & $6.64^{*}$ \\
Kikonge & 7.00 & 7.08 \\
Nyamacumu & 6.60 & 5.14 \\
Kanyawawa & 6.20 & 5.33 \\
St. Edwards & 6.5 & 6.19
\end{tabular}


The $\mathrm{pH}$ values of converted wells remain quite low. According to Lengenegger (1994) it is common for the $\mathrm{pH}$ of water in a well to drop by 0.5 after the installation of corrosion resistant components. A low $\mathrm{pH}$ might also be due to the high populations of bacteria remaining in these wells. Testing in the future may show an increase in $\mathrm{pH}$ as populations of bacteria decrease due to the lack of inorganic iron in the borehole.

A falling $\mathrm{pH}$ over the life of a well could serve as an indicator of bacterial activity. This could prove helpful in diagnosing problems in other wells in the absence of BART ${ }^{\text {TM }}$ test kits. However, it cannot serve as the sole indicator. Kanyawawa has experienced a drop in $\mathrm{pH}$ over its life but was the only well in the area to test negative for IRB. This, however, does not exclude the possibility that SRB could be present in the Kanyawawa well. On the other hand, Kikonge, while testing positive for IRB, has a neutral $\mathrm{pH}$, according to our two data points. The relationship between bacterial activity and $\mathrm{pH}$ should be explored more extensively.

\subsection{Ammonia}

Ammonia is a by-product of the respiration of iron bacteria in connection with corrosion (Langenegger 1994). Ammonia was found in a few of the boreholes in Bwanswa before the intervention and subsequently was not found in those same wells after changing the pipes and disinfecting. Logically, as the IRB population decreased, due to disinfection, ammonia levels should also decrease. Capabilities exist at the district level in Uganda to measure ammonia levels. This could serve as a further indicator of the presence of IRB in the absence of proper test kits. It cannot serve as the sole indicator for two reasons: ammonia can occur naturally in groundwater and only a few of the wells that tested positive for IRB also tested positive for ammonia. 


\subsection{Sulphate}

The presence of sulphate in groundwater is significant because it is used by SRB to produce hydrogen sulfide gas $\left(\mathrm{H}_{2} \mathrm{~S}\right)$ as a by-product of its metabolism. The presence of sulphate can also lower the $\mathrm{pH}$ of a well. Shown below are three wells with sulphate that still had all of their original iron components.

Table 4.4 Sulphate values of wells with iron components

\begin{tabular}{lcc}
\hline Location & $\begin{array}{c}\text { Sample taken after } \\
\text { volume pumped } \\
(\mathbf{L})\end{array}$ & $\begin{array}{c}\text { Sulphate } \\
(\mathbf{m g} / \mathbf{L})\end{array}$ \\
\hline Kigoli $^{2}$ & 20 & 114 \\
Kigoli & 60 & 21 \\
Kigoli & 100 & 20 \\
Kikonge $^{3}$ & 20 & - \\
Kikonge & 60 & 16 \\
Kikonge & 100 & -
\end{tabular}

With the limited data available, we found that a few wells no longer had sulphate in their water after they had been chlorinated and their pipes converted. This may be a result of the disinfection of these wells which would reduce the SRB populations. Kigoli originally had significant amounts of sulphate, as seen in Table 4.4, but, as Table 4.5 shows, none was detected after the change. No data exists for Kyabasaija before it was converted to plastic, but it did show signs indicating the presence of SRB: black slime, smelling like $\mathrm{H}_{2} \mathrm{~S}$, and suffering from localized corrosion. It now has no sulphate after it was changed. Bukumi was the only well showing sulphate after its components were changed to plastic. This may be due to the fact that, since it was an older well, it was fitted with steel casing.

Table 4.5 Sulphate values in $\mathrm{mg} / \mathrm{L}$ of wells changed to plastic

\begin{tabular}{lc}
\hline Location & Sulphate \\
\hline Kigoli & - \\
Kyabasaija & - \\
Bukumi & 6
\end{tabular}

\footnotetext{
${ }^{2}$ Total water volume in borehole: 175 liters.

${ }^{3}$ Total water volume in borehole: 566 liters.
} 
These levels of sulphate were measured by the water lab in Houghton, MI, approximately two months after they were collected. This storage time could have affected the sulphate levels.

\subsection{Results Summary}

Table 4.6 Summary of the most recent characteristics of the five converted wells

\begin{tabular}{lccccccc}
\hline Location & $\begin{array}{c}\text { Depth } \\
(\mathbf{m})\end{array}$ & $\begin{array}{c}\text { SWL }^{4} \\
(\mathbf{m})\end{array}$ & $\begin{array}{c}\text { Pipes } \\
\text { Converted }\end{array}$ & $\begin{array}{c}\text { Iron }^{5} \\
(\mathbf{m g} / \mathbf{L})\end{array}$ & $\begin{array}{c}\text { IRB- } \\
\text { Anaerobic } \\
(\mathbf{c f u} / \mathbf{m l})\end{array}$ & $\begin{array}{c}\text { IRB- } \\
\text { Enteric } \\
\mathbf{( c f u} / \mathbf{m l})\end{array}$ & $\mathbf{p H}$ \\
\hline Kigoli & 40 & 23 & Mar-10 & 0.06 & 50,000 & 0 & 5.72 \\
Bukumi & 87 & 27 & Apr-10 & 0.05 & 50,000 & 500 & 6.64 \\
Bulegete & 22 & 13 & May-10 & 0.39 & 9,000 & 0 & 5.41 \\
Kihurumba & 31 & 14 & Jun-10 & 0.84 & 140,000 & 9,000 & 5.73 \\
Kyabasaija & 47 & 9 & Jun-10 & 0.61 & 50,000 & 500 & 5.51
\end{tabular}

${ }^{4}$ SWL: Static Water Level.

${ }^{5}$ Results from the lab in Entebbe, Uganda of samples taken in September, 2010. 


\section{CONCLUSIONS}

The iron contaminating many deep boreholes in the Bwanswa sub-county originates predominately from down-the-hole iron components such as pipes and rods. The hypercorrosion of these parts releases iron into the water. The cause of this corrosion is microbiological in the form of iron related bacteria and sulphate reducing bacteria. This is commonly referred to as microbially induced corrosion, or MIC. Given that these bacterial groups cannot be eradicated permanently, the best available option is to remove the iron parts and install corrosion-resistant components in the form of PVC riser pipes and stainless steel rods. Disinfection, although not essential for lowering iron concentrations, is also beneficial before allowing the water to be used by communities.

Even though the component conversion effort succeeded in reviving 5 boreholes in Bwanswa, this cannot be touted as the one-size-fits-all solution for iron contamination. Other areas of the country where significant amounts of iron are coming from geological formations may require a different intervention, such as an iron removal plant. If IRB exists in a well in conjunction with iron coming from formation then a component conversion and an iron removal plant would be in order. However, since it is difficult to tell where the iron originates, a sensible first step would be to test for IRB, SRB, and $\mathrm{pH}$. If corrosion is being experienced, then the pipes should be immediately converted.

A researcher in the early 1990s looked at the effectiveness of over 8000 iron removal plants (IRPs) in India. Frustrated by the water quality which was deteriorating due to bacterial action, and the number of abandoned IRPs, which were caused by community maintenance issues, he gave this statement:

"When we reached the conclusion that PVC pipes and stainless steel rods used on the handpump could substantially reduce the rate of deterioration of water quality, we stopped building IRPs.” (Daw 1991)

Considering this conclusion, the current strategy to reduce the iron contamination in Ugandan wells, through the use of IRPs, should be re-examined. At the very least, an IRP should not be installed in an application that still has its iron pipes and components.

These bacterial populations could be coming from contaminated components of drilling rigs. Policies need to be instituted requiring the drilling sub-contractors to properly disinfect their drill rigs so as to curb the spread of IRB and SRB. Drilling companies refusing to follow such procedures should be barred from winning contracts. 
I would also strongly suggest that the policy makers at the Ministry of Water and Environment require that all new boreholes installed in these problematic regions, requiring no more than 45 meters of riser pipe, be fitted with the India Mark III-modified pump from the start. As their prices are quite similar, this would not come at a great cost to the installer, and it would limit the community maintenance necessary as well as prevent potential water quality issues in the future. This would be a strong step towards promoting sustainable clean water coverage in the country. 


\section{FUTURE WORK}

Further investigation in these problematic regions regarding the breadth of the IRB and SRB contamination should be conducted. Links should be explored between the wells that suffer from iron contamination within this belt of districts. The following possibilities could be investigated: Is IRB inherent in their soils? Is there a geologic explanation? Or is there a link to one or more contaminated drilling rigs? The IRB-BART ${ }^{\mathrm{TM}}$ and SRB-BART ${ }^{\mathrm{TM}}$ tests are available for a reasonable cost and give practical information for solving the iron issue and remediating abandoned boreholes for the health of the people of Uganda.

Further work could be done in studying the ability to diagnose a borehole's contamination with IRB and/or SRB in the absence of BART ${ }^{\mathrm{TM}}$ test kits. Researchers could explore the possibility of establishing particular parameters, measurable by instruments available at the district level, which would give definitive indications of the presence of such bacteria, such as: $\mathrm{pH}$, ammonia, and visual clues.

In areas of the country where wells are still producing iron but IRB and corrosion are not problematic, further studies could be conducted on developing a low-maintenance iron removal solution that would enjoy full community acceptance.

These five wells in Bwanswa should be revisited to see if this remedy has remained effective over a longer period of time. If the iron has returned, then further investigation should be conducted into the efficacy of periodic chlorination as a means to control the iron levels. Disinfection doses and intervals could also be explored. 


\section{BIBLIOGRAPHY}

Ahmed F, Smith P. 1987. Design and Performance of Community Type Iron Removal Plant. Journal of the Institute of Water Engineers and Scientists. 41(2):167-172.

ADF (African Development Fund). 2005. Appraisal Report: Rural Water Supply and Sanitation Program. Infrastructure Department: North, East, and South Region.

AWWDA (Alberta Water Well Drilling Association) [Internet]. 2008. Lougheed, AB. Shock Chlorination Information; [Cited March, 2010]. Available from: http://www.awwda.com/shock.html

Cullimore DR. 1993. Practical Manual of Groundwater Microbiology. Chelsea (MI): Lewis Publishers.

Daw RK. 1991. Results of Field Trials - India Mark II Solid Link Suction Pumps May 1988 to March, 1991. Danida Project Directorate.

DWD (Directorate of Water Development-Uganda) and Danida (Danish International Development Agency). 2002. Innovations Applied in Research in the Water Sector, DWD official report.

Free World Maps [Internet]. 2006. Physical Map of Uganda; [Cited Dec, 2010]. Available from: http://www.freeworldmaps.net/africa/uganda/map.html. Used with permission through the Creative Commons Attribution-ShareAlike 2.5 License, See Appendix C for documentation that this material is in the public domain.

Government of Uganda [Internet]. 2006. Opportunities for Mining Investment; [Cited Jan, 2011]. Available from: http://www.magnusresources.com/ docs/media/UgandaMining2006.pdf Used with permission as explained on page 2 of the document.

Kaciel M. 2004. Iron removal: Pilot Project in Rakai District, Uganda. MSc Thesis Cranfield University, UK

Lachat Instruments [Internet]. 2010. Methods List for Automated Ion Analyzers; [Cited Jan, 2011]. Available from: http://www.lachatinstruments.com/download/LL022-Methods$\underline{\text { List 5-10.pdf }}$ 
Langenegger O. 1994. Groundwater Quality and Handpump Corrosion in Africa. UNDPWorld Bank Water and Sanitation Program.

MCCHD (Missoula City-County Health Department) [nternet]. Well Disinfection Procedure; [Cited Dec. 2010]. Available from: http://www.co.missoula.mt.us/ENVHealth/WaterServices/pdfs/WellDisinfection.pdf

Misstear B, Banks D, Clark L. 2006. Water Wells and Boreholes. West Sussex, England: John Wiley \& Sons Ltd.

MWH. 2005. Water Treatment: Principles and Design. $2^{\text {nd }}$ ed. Hoboken (NJ): John Wiley \& Sons Inc.

S.K. Industries [Internet]. 2008. Published by Websity. India Mark 2 Handpump; [Cited Oct. 2010]. Available from: http://skipumps.com/mark2 details.htm Used with permission from Sharad Jhunjhunwala as per email communication. See Appendix C for documentation of permission to republish this material.

Sentumbwe A. 2009. A Proposal for Scaling Up Iron Removal Plants in Uganda. DWD Official Report for the Ministry of Water and Environment of the Republic of Uganda. Graphic used with permission from author as per email communication. See Appendix $\mathrm{C}$ for documentation of permission to republish this material.

Tyrrel SF, Howsam P. 1997. Aspects of the Occurrence and Behaviour of Iron Bacteria in Boreholes and Aquifers. Quarterly Journal of Engineering Geology. 30: 161-169.

WHO (World Health Organization) [Internet]. 2006. Guidelines for Drinking-Water Quality; [Cited Nov. 2010]. Available from: http://www.who.int/water sanitation health/dwq/GDW10rev1and2.pdf

WHO (World Health Organization) [Internet]. 2010. World Health Statistics; [Cited Nov. 2010]. Available from: http://www.who.int/whosis/whostat/2010/en/index.html

WWAP (World Water Assessment Program) [Internet]. 2006. National Water Development Report: Uganda; [Cited Jan. 2011]. Available from: http://unesdoc.unesco.org/images/0014/001467/146760e.pdf

Yuzwa GF. 1991. Corrosion by Sulphate Reducing Bacteria. Presented at Alberta Public Works, Supply and Services. Edmonton, Alberta. 


\section{APPENDICES}

\section{A. Dependency}

Uganda is a county that is dependent upon foreign aid. Many foreigners come to Uganda with the best intentions and do seemingly good work that has a strong immediate impact. However, over the last two years I grew to see the ugly underbelly of aid work. While many of these projects helped many people in the short run, the long term consequences are sometimes disastrous. Such is the way stereotypical grandparents come around for a weekend and draw great joy from lavishing gifts on their grandchildren. Indeed, their grandchildren also derive great enjoyment from these gifts. However parents draw a greater joy from seeing their children grow up to have strong character and be independent and self-reliant. Lavishing gifts on children does not encourage the development of a strong work ethic, nor does it instill a sense of self-reliance.

Due to the shortsighted policies of many international organizations, they have operated, and continue to operate, in such a manner that arguably does not instill a strong work ethic and independence in the hearts of the Ugandan people. These organizations are strongly donordriven and thus come with their own agendas. Their development strategy is top-down in orientation. While this strategy perpetuates the existence of these certain organizations, it comes at a high cost: the dignity of the people of Uganda.

In our work, we found the aid dependency disease to be rampant. A vast majority of the population in Bwanswa do not take responsibility for their own development. The transliteration of a common phase used in the local language is to "get a chance." People simply pass time until their 'chance' or stroke of luck comes along. These 'chances' usually take the form of a certain handout or program sponsored by an international organization. But until this 'chance' arrives, many perceive that all that can be done is to sit back and enjoy life. This gives way to the rampant alcoholism destroying the health and productivity of the working class. The poor quality education in the area and the example set by many parents gives children little to dream about. Most figure they will just grow the little food they need to survive and pass the time drinking their local alcohol while waiting for their 'chance' to finally present itself.

When we visited communities to talk to their leaders, more often than not, we were greeted with the description of a host of problems faced by the community. Many of these issues could be solved by a strong leader organizing the people to tackle their problems together. However, this rarely happens. As we asked about water resources in the community, we were often told that they either had a broken borehole or had a borehole that produced bad water. This was always followed by a plea, asking us to come repair the wells. When we inquired 
about the specific problem with the broken pump, usually it had never been diagnosed. But the deeper issue is that the community members did not believe that the responsibility for fixing their water source rested on their shoulders. They have been conditioned to assume that either a benevolent NGO or the government is bound to come and fix it for them, and until that happens, they often believe they can only suffer at the hands of fate.

We quickly realized that the issue of sustainable clean water coverage was not threatened nearly so much by the issue of hardware as it was by the mentality that had been instilled into the hearts and minds of the Ugandan people by well-meaning foreigners. 


\section{B. Water User Committees}

Our strategy was one of 'playing catch' with the community and its leaders. We wanted to be as far away from a top-down approach as possible, and thus we never acted without the full cooperation and consent of the community members. This usually took the shape of our organization initially being invited into a community to help repair the local water source. We would meet with the leaders and have a very open discussion about how we operated differently than other organizations that they had worked with, or benefited from, in the past. We made it clear that we would give them nothing but knowledge and would require hard work from them. We were also very adamant that we would only work as hard as they worked and that we would never operate without them. At the end of the first meeting we would require the leaders to mobilize the current Water User Committee (WUC), if one existed, or to hold elections to form a new WUC. We were then to be informed so that we could come and have a meeting with the WUC. We made it clear that we would not return until we were called to do so after they had completed their end of the bargain. Depending on the strength of the community leadership, we waited anywhere from 1 day to 3 months for a response, and sometimes the communities never did respond.

Once we were called back to meet with the WUC we tried to come as quickly as possible to uphold our end of the bargain and to keep the momentum of the community going. In a continual effort to break the top-down tendency of development work we employed the Socratic method in our trainings. I wanted the WUCs to come up with their own thoughts and ideas about why the borehole was not working, what could be done to ensure that it continually functions in the future, who suffered when the borehole was not functioning and therefore, whose responsibility it was to fix and maintain the water source, etc. I provided no answers, only leading questions. These were usually exciting meetings in which, through selfdiscovery, the WUC felt empowered to take control of their own development and the health of their community. These meetings often lasted for hours, but by the end, the WUC had usually come up with a set of by-laws and an action plan for mobilizing their community to instill in their peers the same sense of responsibility they were now bearing. The meetings finished by asking the WUC to contact us again when they had successfully mobilized the whole community and collected donations to the maintenance fund from every member of the community.

The community contribution was an indicator as to how successful the WUC was in educating their peers on their civic responsibility to sustain their improved water source. At the end day, it comes down to simple economics. In general, people will only part with their money for things they deem important. The breakdown in the Ugandan system stems from two primary misunderstandings within the community: a misunderstanding about the importance of clean 
water for health and a misunderstanding of whose responsibility it is to maintain these community water sources. Although members of the WUC were met with a considerable amount of resistance as they educated their peers on the above two issues, more often than not, within a few weeks or months, the WUCs were eventually successful.

Only after the whole community was organized and convinced of their civic duties did we return and introduce the sub-county pump mechanics to the WUC and allow the two parties to negotiate the labor fees. Then the two pump mechanics and I, along with several strong volunteers from the community, began the process of dismantling the pump mechanism to diagnose the problem. These days were usually quite festive. Most of the community gathered to watch the repairs take place. Lunch was usually provided by local women for those doing the work. If all went as planned and the well did not suffer from iron contamination but rather just had an issue requiring an available part, then usually within a day the well was producing water. If the problem was more extensive, requiring more funds to be raised, then the work was put on hold until the community could supply the money needed to purchase the replacement parts.

At the very beginning of this whole project I made a contract with two pump mechanics named Bulemu and Desitayo. They had been trained through the government initiative explained above. However, their skills were unrefined and their tool collection was meager. We made an agreement that they would work with me for the duration of time that I was in Uganda in exchange for a proper set of tools for maintaining these boreholes. Throughout our time we became not only a good team but also great friends. They taught me their tricks of the trade that they had learned through experience, and I taught them theory and problem solving that I had learned through education. These men are now well known throughout their subcounty and are equipped to carry on the effort of working towards sustainable clean water coverage. 


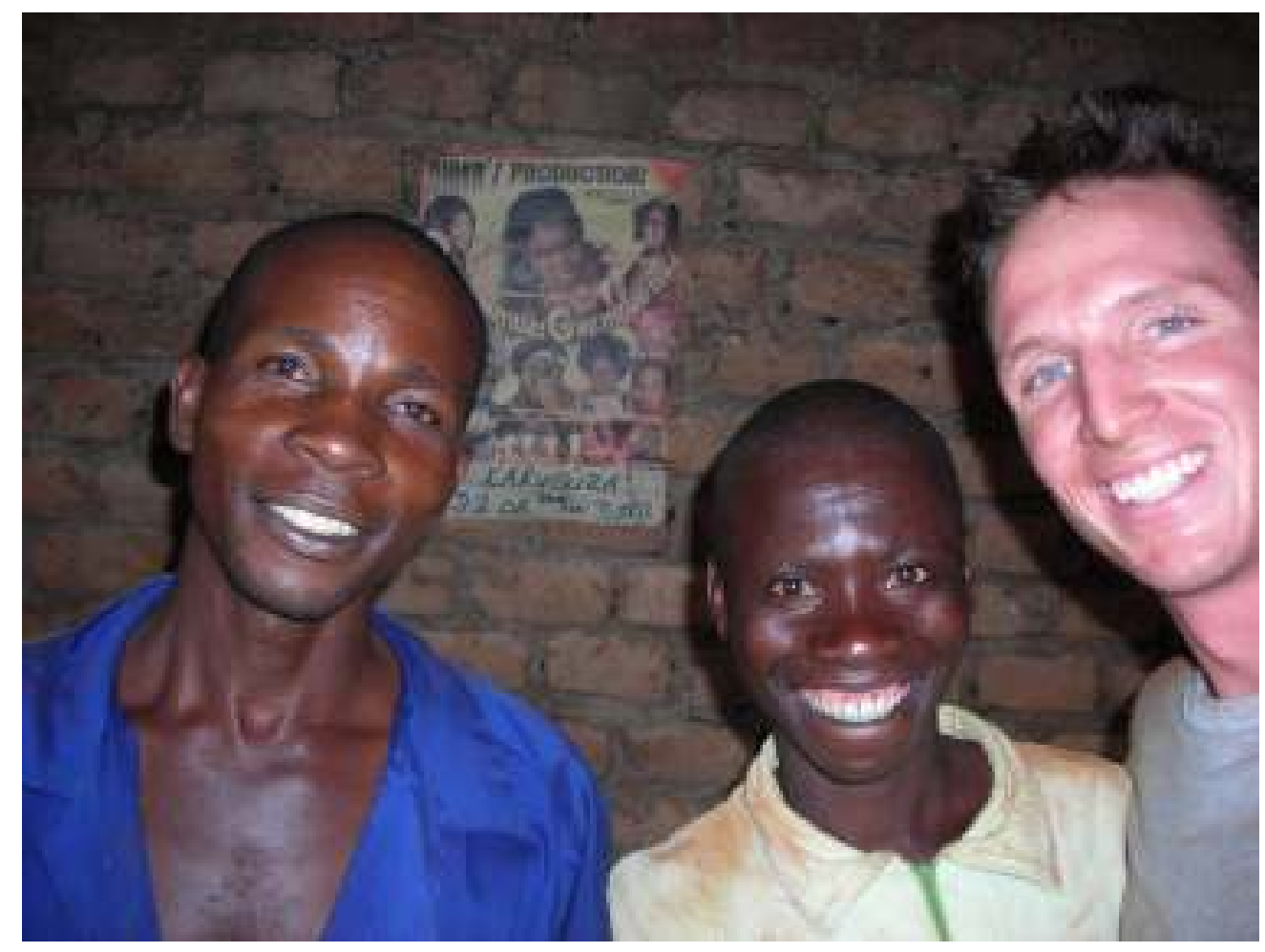

Figure 6.1 Desitayo, Bulemu, and Caleb Fader (photograph by author) 


\section{Figure 1.1}

As stated on the website http://www.freeworldmaps.net/:

Unless specifically stated otherwise, all maps on this website licensed under a Creative Commons Attribution-ShareAlike 2.5 License, appropriate attribution required as a visible and clickable hyperlink to http://www.freeworldmaps.net/, or the direct URL of the page containing the relevant map.

\section{Figure 2.1}

India Mark II Graphic from skipumps.com

Email Communication on Mon, Dec 6, 2010 at 1:23 am

RE: India Mark II graphic

From: Sharad Jhunjhunwala jhunjhunwala.sharad@gmail.com

To: Caleb Fader calebfader@gmail.com

Dear Caleb,

You are free to use the drawing with credit.

Regards

Sharad

\section{Figure 2.5}

Email Communication on Mon, Dec 6, 2010 at 12:44 AM

RE: Silsoe Iron Removal Plant Graphic

From: Ahmed Sentumbwe ahmed.sentumbwe@mwe.go.ug

To: Caleb Fader calebfader@gmail.com

Hullo Caleb!

It is greet to here from you! In fact I had discussed your presence in the country with the commissioner and I was waiting for you to return and we review the progress. Any way I am happy that you are putting something on paper. I dont have objection for you to include my 
work as part of your write up! As it for the benefit of the water sector! Wish you lack in your endovours!

Eng. Ahmed Sentumbwe 
D. Driller Logs for Wells in Bwanswa

\begin{tabular}{|c|c|c|c|c|}
\hline Location & $\begin{array}{l}\text { Up to } \\
\text { Depth } \\
\text { (m) }\end{array}$ & Lithology & $\begin{array}{c}\text { Static } \\
\text { Water } \\
\text { Level }(\mathrm{m})\end{array}$ & $\begin{array}{c}\text { Constant } \\
\text { Discharge } \\
\text { Yield } \\
\left(\mathrm{m}^{3} / \mathrm{hr}\right) \\
\end{array}$ \\
\hline Kigoli & $\begin{array}{c}8 \\
25 \\
40 \\
43\end{array}$ & $\begin{array}{l}\text { Top loam soil, Laterite } \\
\text { Brownish Clay and Course Quartz } \\
\text { Highly Fractured Granite } \\
\text { Stable Granite }\end{array}$ & 21.6 & 0.80 \\
\hline Bukumi & $\begin{array}{c}3 \\
12 \\
24 \\
40 \\
87\end{array}$ & $\begin{array}{l}\text { Top Soil } \\
\text { Laterite } \\
\text { Clay } \\
\text { Sandy stone } \\
\text { Gneiss }\end{array}$ & 27.0 & 0.20 \\
\hline Bulegete & $\begin{array}{l}18 \\
22 \\
25\end{array}$ & $\begin{array}{l}\text { Top Loam Soil Laterite } \\
\text { Granite } \\
\text { Granite Boulders }\end{array}$ & 12.9 & 1.00 \\
\hline Kihurumba & $\begin{array}{c}0.5 \\
5 \\
22 \\
25 \\
66\end{array}$ & $\begin{array}{l}\text { Loamy Soil } \\
\text { Laterite } \\
\text { Clay } \\
\text { Weathered Granite } \\
\text { Granite }\end{array}$ & 13.9 & 0.61 \\
\hline Kyabasaija & $\begin{array}{c}5 \\
30 \\
52\end{array}$ & $\begin{array}{l}\text { Top Black Loam Soil } \\
\text { Sandy Soil } \\
\text { Fresh Granite }\end{array}$ & 8.4 & 0.85 \\
\hline Kikonge & $\begin{array}{c}1 \\
5 \\
17 \\
27 \\
38 \\
\\
61 \\
71\end{array}$ & $\begin{array}{l}\text { Black soil } \\
\text { Reddish soil, Laterite } \\
\text { Brownish Clay and Sand } \\
\text { Weathered Granite } \\
\text { Slightly Hard Granite } \\
\text { Hard Granite with Course } \\
\text { Particles } \\
\text { Fresh Granite }\end{array}$ & 15.6 & 0.80 \\
\hline Kasojo & $\begin{array}{c}4 \\
14 \\
28\end{array}$ & $\begin{array}{l}\text { Top, Red Soil } \\
\text { Clay } \\
\text { Weathered Gneiss }\end{array}$ & 14.5 & 0.77 \\
\hline
\end{tabular}




\begin{tabular}{|c|c|c|c|c|}
\hline & 48 & Fractured Gneiss & & \\
\hline & 70 & Fresh Granite & & \\
\hline Kacururu & 1 & Top Soil & 17.2 & 4.04 \\
\hline & 19 & Clay & & \\
\hline & 23 & Grayish Clay & & \\
\hline & 36 & Weathered Gneiss & & \\
\hline & 60 & Fresh Gneiss & & \\
\hline Kanyawawa & 1 & Top Black Soil & 11.0 & 0.60 \\
\hline & 9 & Laterite & & \\
\hline & 18 & Clay & & \\
\hline & 41 & Weathered Granite & & \\
\hline & 47 & Fractured Granite & & \\
\hline & 50 & Fresh Granite & & \\
\hline Rwensera & 0.5 & Loam soil & 12.7 & 2.40 \\
\hline & 5 & Laterite & & \\
\hline & 24 & Misc. Clay & & \\
\hline & 35 & Weathered Granite & & \\
\hline & 52 & Fresh Granite & & \\
\hline St. Edwards & 1 & Top black soil & 22.4 & 2.16 \\
\hline & 7 & Reddish soil & & \\
\hline & 18 & Clay & & \\
\hline & 27 & Fractured weathered rock & & \\
\hline & 44 & Fresh Granite & & \\
\hline Nyamacumu & 5.3 & Top soil Laterite & 20.4 & 6.00 \\
\hline & 18.9 & Quartz and sand & & \\
\hline & 34 & Weathered quartzite & & \\
\hline & 43 & Highly fractured granite & & \\
\hline & 46 & Fresh granite & & \\
\hline Ug. Martyr's & 4 & Black sticky top soil & 3.6 & 3.40 \\
\hline & 18 & Brownish yellow clay with gravel & & \\
\hline & 79 & Granite & & \\
\hline
\end{tabular}




\section{E. Aquifer Calculations for Kigoli}

Using an ideal radial flow equation with no leaks (essentially a mass balance) we can find an average daily velocity of groundwater. Because very little is known about the geological conditions the following assumptions have been made: a homogeneous and isotropic aquifer with infinite extents, and casing extending to the bedrock:

$\bar{v}=-\frac{Q_{w}}{2 \pi b n r}$

Where:

$Q_{w}:$ is daily flow where:

$Q_{w}=(15$ households $) \times\left(\frac{8 \text { people }}{\text { household }}\right) \times\left(\frac{10 \mathrm{~L}}{\text { person } \cdot \text { day }}\right)=1.2 \frac{\mathrm{m}^{3}}{\text { day }}$

b: is the aquifer thickness

$n:$ is porosity which was estimated at $10 \%$ for fractured crystalline rock aquifer

$r$ is the radius offlow (estimated from Google maps)

$\bar{v}=-\frac{1.2 \frac{m^{3}}{d a y}}{2 \pi(15 m)(.1)(270 m)}=-4.71 E^{-4} \frac{m}{d a y}$

Therefore, the time to travel $270 \mathrm{~m}$ would be 572,555 days or 1567.6 years. 
